University of Wollongong

Research Online

Faculty of Business - Papers (Archive)

Faculty of Business and Law

January 2020

The what and how of Family business paradox: Literature-inspired distillations and directions

Mary Barrett

University of Wollongong, mbarrett@uow.edu.au

Ken Moores

Follow this and additional works at: https://ro.uow.edu.au/buspapers

Research Online is the open access institutional repository for the University of Wollongong. For further information contact the UOW Library: research-pubs@uow.edu.au 


\title{
The what and how of Family business paradox: Literature-inspired distillations and directions
}

\author{
Abstract \\ The purpose of this article is to review and comment on the literature on family business paradox against \\ the backdrop of Moores and Barrett's 4Ls learning framework. This framework outlined the learning \\ paradoxes, priorities and pathways that successful family business CEOs identified and coped with in \\ their learning journeys. A 'what and how' theme emerges from our literature review (203 items) where we \\ identify both confirmations and deficiencies in the 4Ls framework - deficiencies that suggest future \\ research opportunities. Research directions are distilled in the form of questions that extend the 4Ls by \\ enhancing the model both within it and by connecting it with adjacent areas.

\section{Publication Details} \\ Barrett, M. A. \& Moores, K. (2020). The what and how of Family business paradox: Literature-inspired \\ distillations and directions. The International Small Business Journal, 38 (3), 154-183.
}




\title{
The what and how of family business paradox: Literature inspired distillations and directions
}

\begin{abstract}
The purpose of this paper is to review and comment on the literature on family business paradox against the backdrop of the 4Ls learning framework. This framework outlined the learning paradoxes, priorities, and pathways that successful family business CEOs identified and coped with in their learning journeys. A 'what and how' theme emerges from our literature review where we identify both confirmations and deficiencies in the 4Ls framework - deficiencies that suggest future research opportunities. Research directions are distilled in the form of questions that extend the $4 \mathrm{Ls}$ by enhancing the model both within it and by connecting it with adjacent areas.
\end{abstract}

\section{Keywords}

Paradox, Family firm, Literature review, Contradiction, Innovation, Entrepreneurship, Learning, Succession

The paradoxical nature of organizational life has been widely discussed in business and management since the mid-1980s (e.g., Handy 1994; Lewis 2000; Putnam 1986; Poole and Van de Ven 1989) and paradox remains an important source of management insight. Paradox is generally understood as contrary or even contradictory propositions which are driven by apparently sound arguments (van Heigenoort 1972:45, cited in Poole and Van de Ven 1989). Organizational paradoxes include a wide variety of contradictory yet interwoven elements: perspectives, feelings, messages, demands, identities, interests, or practices that arise from actors' attempts to make sense of an ambiguous world (Lewis 2000:761). Unlike theoretically simpler kinds of organizational problems, which disappear after an appropriate solution is implemented, paradoxes cannot be made to vanish. Even to try would be counterproductive, because it would suppress the gains that result from appreciating both sides of an enduring contradiction. Instead, managing paradoxical tensions involves acknowledging complex links between opposing forces. This gives meaning to apparent contradictions and allows people to cope with them. Indeed 'coping' reflects the original meaning of management (Handy 1994) rather than the modern connotations of planning and control.

All firms - family and nonfamily - are subject to these contradictions, but combining the features of family and business - two unlike systems - makes family firms more difficult to manage. Early researchers noticed this, for example Tagiuri and Davis (1996) and Stafford et al. (1999) who pointed to family firms' 'bivalent attributes' which lead to both advantages and disadvantages. Moores and Barrett's 2002 book, Learning Family Business: Paradoxes and Pathways, broke new ground in its focus on the paradoxes that aspiring successors confront when learning to lead family businesses. They discussed not just what paradoxes arose from combining family and business, but how these differences created special learning paradoxes that those seeking family firm leadership needed to cope with. The value of paradox for understanding family business has persisted; indeed Family Business Review, the pre-eminent journal in the field, was founded with the aim of 'better understanding the paradoxes faced by the owners and managers of family enterprises' (Sharma et al. 2012:8). Nevertheless, so far as we know there has been no systematic literature review since Moores and Barrett (2002) that would give a comprehensive picture of the paradoxes inherent to the nature of family businesses and the paradoxes of managing them. The key contribution of this paper is thus a systematic literature review of 203 items informed by the 'what' and the 'how' of family business paradox in the 17 years since then.

This commentary is structured as follows. First, we briefly recap the 4Ls framework, then explain the method used to review the literature. The results concerning each item's geographical context, its basic approach, and what it said about paradox, are available at Appendix 1. We then present the two broad themes our review revealed: paradoxes arising from the nature of family firms, i.e., 'what' paradoxes; and the paradoxes of managing (and learning to manage) them, i.e., 'how' paradoxes. We link both themes to the 4Ls model, often confirming it, but sometimes showing where it is deficient. The next section examines new and interesting research questions which arise from looking 'inside' the model (revisiting its components and their relationships) and looking 'outside' it (at potential links to concepts and frameworks in adjacent areas). 


\section{The 4Ls in brief}

Moores and Barrett (2002) developed the 4Ls model via a qualitative study which sought to understand how leaders of family firms learned to manage the special complexities of family firms. Analysis of 17 such cases in Australia across a variety of industries, showed how combining family and business led to unique paradoxes in what future CEOs must understand and do to become competent to lead family firms. Findings were summarized in four sequential learning phases.

L1: Learn business In L1 future leaders acquire skills to develop the firm, a difficult task if undertaken only inside the family firm. They need to gain experience outside it to view it critically and demonstrate to themselves and family members that they are capable businesspeople.

...its paradox Encountering change reveals tensions between old and new (Lewis 2000). Moreover, successors who leave the firm may create a satisfying career outside and never return, threatening the incumbent's goal of keeping the business in family hands. Finally, choosing a leader from the family means a much smaller talent pool compared with nonfamily firms.

...its priority Business proficiency, both personal and technical, is the L1 priority. Personal skills of discipline, self-awareness, and self-management are even more important than the technical skills of business.

...and the pathway through it Gaining outside experience is so important that successors 'go outside anyway'.

L2: Learn our family business In L2 future leaders learn our business: the special qualities of this particular family business. This is the obverse of L1. L2 often starts very early via stories passed down from earlier generations, so its lessons are reinforced by emotion. However, they can also create dangerous inertia.

...its paradox L2 demands that future family firm leaders appreciate the special qualities and broad strategies of the family business but do so critically and with an eye to necessary change. So the L2 paradox is to 'continue differently'.

...its priority L2's priority is to perpetuate values, that is, create a sense of continuity so that, despite change, family members and customers see the firm as 'the same' family business. It often turns out that family firm values also have market value - another paradox.

...its pathway The pathway through the 'continue differently' paradox is to keep the business's principles and philosophies and discard outdated detail.

L3 Learning to lead our family business Family firm leaders need to take a 'helicopter view' of the firm and understand its position in its lifecycle. With growth, it is often necessary to professionalize the firm.

...its paradox Professionalizing the family firm requires 'formal informality' to manage Lewis's (2000) paradox of organizing: simultaneous demands for control and flexibility. Unlike nonfamily firms, leaders must preserve the family qualities of commitment and trust, while gradually introducing more formal controls.

...its priority Family firm leaders need perspicacity to balance formal and informal controls.

...its pathway The pathway through the 'informal formality' paradox is to professionalize the firm's strategy, structure, and systems, using a light touch.

L4 Learning to let go L4 is often difficult because it can mean loss of identity and purpose for the incumbent while realigning organizational goals. It occurs more rarely than in nonfamily firms, and is more likely to include ownership as well as management transfer. 'Letting go' creates a belongingness paradox (Lewis 2000) whereby the incumbent must help the successor to do things differently, partly by 'getting out of the way'.

...its paradox Learning to let go is paradoxical because family firm leaders must anticipate what the firm will need when they are no longer leading it. In short, they lead in order to leave.

...its priority The priority of the L4 leader is prescience: anticipating their own future needs and smoothing the successor's pathway to leadership.

...its pathway To carve a pathway through these tensions, family firm leaders develop a timeline for retirement, create management development systems, then stick to the plan.

Figure 1 presents these phases at their simplest. 


\section{Place Figure 1 about here.}

Our identification of distinctive paradoxes that prevail in the context of the learning journeys for aspiring family business leaders now calls for a review of the subsequent literature to distil the nature and form of family firm paradoxes, especially those associated with successor development.

\section{Method to explore current state of the field}

Following Tranfield et al. (2003) we first defined the topic and corresponding keywords. Articles and other items were sought where 'family business*', 'family control*', 'family firm*', 'family led' or 'family own*' appeared in the title, abstract, keywords, or references. These terms were combined with 'paradox*' or 'contradict*' (related constructs, often used synonymously) and 'learn*' appearing anywhere in the text. Adding asterisks to the search terms caught variations such as 'family owned' and 'family businesses'. We sought peer-reviewed items, including articles, research notes, working papers, books, conference papers, and full papers. We also wanted to see how non-academic sources such as the business media and management blogs have treated paradox, so we added these source types. We achieved a broad search by applying this protocol to the Proquest Central database, which searches six different databases, and the Sage database which covers several journals important for family business research not covered by Proquest Central, including Family Business Review and Entrepreneurship Theory and Practice. Items in languages other than English and duplicate items were excluded. Each item's abstract and full text were read to ascertain their topic fit. Their references were also checked and promising items read (Fink 2005). Because Moores and Barrett's book was published in 2002, we included results from 2003 onwards. We sought out the most recent research by checking the citations of key articles and researchers' publication lists (Booth et al. 2011; Fink 2005). The first author evaluated all the items, sending the other author a written summary of each including a justification for including or excluding the item. We discussed any disagreements and negotiated a consensus. Applying this method yielded 203 papers.

We collated the items' basic method and geographic focus, to give an overview of the type of study and because knowing the cultural context of a piece of research aids in understanding the findings. We then coded the items via a content analysis. For each item, we noted what topic or problem was linked to paradox, for example, innovation, firm reputation, succession, governance, tax law, and so on. There were numerous such topics and problems; these will be discussed in the next section. Despite their variety, we could readily classify them into two broad categories: paradoxes arising from the inherent features offamily firms which are sources of tension, coded as 'what' paradoxes; and paradoxes that were apparent in how families seek to cope with or manage these paradoxical tensions, coded as 'how' paradoxes.

\section{Themes emerging from the literature review}

Ingram et al. (2016) was particularly influential in our analysis of themes emerging from the results. The authors focus on innovation in family firms in the context of family firm paradox. Endorsing Schuman et al.'s (2010) view that three broad paradoxes characterize family firms: tradition versus change, family liquidity versus business growth, and founder control versus successor autonomy, they use the family business and organizational paradox literatures to develop measures of paradoxical tensions and paradoxical thinking in family firms. Applying these measures in a multi-stage exploratory study revealed that paradoxical tensions may stymie innovative behavior, but leaders' paradoxical thinking is positively related to innovative behavior.

Ingram et al.'s finding that paradoxical thinking enables positive behaviors and paradoxical tensions reduce them, resembles our two-way grouping of 'what' paradoxes (inherent family firm features that are the source of tensions) and 'how' paradoxes (paradoxical ways family firms manage these tensions). Nevertheless, their assertion that there are only three broad family business paradoxes seemed surprising given the large number of apparently contrasting paradoxical topics and problems that emerged in our analysis. Accordingly, we compared our 'what' paradoxes and 'how' paradoxes with both the 4Ls and the 'three basic paradoxes of family business' discussed in Schuman et al. and Ingram et al. See Table 1.

Place Table 1 about here.

What is paradoxical about family business 
Table 1 shows that the 'three paradoxes' finding of Schuman et al. (2010) and Ingram et al. (2016) has some justice: our 'what' paradoxes all map onto one or more of their three basic paradoxes. For example, Litz (2012) discusses the paradox of conformity vs. non-conformity: the double-bind message sent out by family business owners to their children. Entrepreneurial ideology encourages children to make their own way in the world, but family business ideology often encourages subservience and obedience. Hjorth and Dawson (2016) refer to the same paradox as 'the impossible gift of succession'. These papers and many others are commensurate with Ingram et al.'s 'founder control vs. successor autonomy' paradox.

The paradox of entrepreneurial success discussed by Wasserman (2003) and Zhao et al. (2018) arises in family firms because founders typically have long tenure and are likely to develop a strong commitment to existing strategies, a possible source of strategic inertia. Again, the likely result is that family firms will tend to maintain tradition and resist strategic change. Similarly, the initiative paradox was originally discussed by Campbell (2001) in the non-family firm context, but has been applied to the family complex by Marler (2017) who studied 'personality incongruences' between CEOs of family firms and successors. A typical and non-paradoxical - personality incongruence arises when a proactive incumbent has difficulty persuading a more passive successor to take over family firm leadership. But a paradox arises when the incumbent and the likely successor have similar, proactive personalities. Proactive leaders expect their followers to have expanded role definitions and to take initiative as they would themselves. Proactive individuals tend to define their roles broadly, and proactive aspiring successors may take on roles beyond their formal job descriptions. Incumbents may see this as too much initiative, leading them to actually reduce the successor's discretion despite wanting to hand over leadership. Again the likely result is less strategic change, consistent with the 'tradition vs. change' paradox.

Lin and Wang (2019), who studied the speed with which serial entrepreneurs start new ventures following failure, suggest that the embeddedness paradox ${ }^{1}$ might explain why family involvement does not expedite re-venturing. The embeddedness paradox refers to the risk-aversion created in successors by highly entrepreneurial founders: successors fear that if they take risks they may waste the resources the founder built up for the famiy. ${ }^{2}$ Fear of wasting these resources would encourage family firms to keep to their traditional products and methods, consistent with the 'tradition vs. change' paradox, and reluctant to grow, as predicted by the 'family liquidity vs. business growth' paradox.

Several authors discuss the ability vs. willingness to innovate paradox, notably Casprini (2017), Chrisman et al. (2015), De Massis et al. (2014), and De Massis et al. (2015). It refers to the finding that family firms have superior ability yet lower willingness to engage in technological innovation, causing differences in behavior and performance between family and nonfamily firms as well as among family firms. Family firms have superior ability to direct resources towards innovation given their personalized control, low levels of formalization and bureaucracy, long-term investment horizons, patient capital, altruism, and interest alignment between owners and managers (Carney, 2005; Schulze et al. 2001; Sirmon and Hitt, 2003). However, innovation also entails significant risk, requires a strong commitment of resources, takes time to produce tangible outcomes, and can lead managers to operate in domains where results are unpredictable and the need for external resources is greater. Accordingly, family firms are typically seen as less willing to innovate through risk-aversion, lack of the requisite skills within the family, and reluctance to share control with nonfamily managers who do have the skills (Garcia and Calantone 2003; McDermott and Colarelli O'Connor 2002). They have a particular comparative disadvantage for more radical innovations (market novelties) (Schäfer et al. 2016) because, reflecting the paradox of entrepreneurial success, they may be overly committed to their traditional products and prefer to minimize the need for external financing. The ability vs. willingness to innovate paradox thus aligns with all three of Ingram et al.'s basic paradoxes.

Thus far we have discussed the 'what' paradoxes revealed by our literature review, that is, paradoxes arising from the idiosyncratic features that result from combining family with business. Each leads to,

\footnotetext{
${ }^{1}$ The embeddedness paradox is different from local embeddedness, that is, the involvement of economic actors in a geographically bound social structure-particularly in rural and urban contexts (Bau et al. 2019; Uzzi 1999). Bau et al., in a study of privately held Swedish firms, found that family firms benefit more than nonfamily firms from local embeddedness, achieving higher levels of growth. The effect was more pronounced in rural areas.

2 Researchers occasionally give different names to the same paradox. What Lin and Wang (2019) call the 'embeddedness paradox', Berent and Uhlaner (2012) refer to as 'the paradox of the enterprising family'.
} 
reinforces, or at least resonates with one or more of Ingram's three basic paradoxes. However the 'how' paradoxes, those that concern how leaders cope with these paradoxical features, are not so readily reducible. We identified many 'how' paradoxes. Some, such as the roots and wings paradox, were related to learning and successor commitment and competence; others deal with managing chaos, innovation, and perpetuating values. They present ways of managing the 'what' paradoxes: the tensions or contradictions that make family businesses complex and hard to manage. We first consider 'how' paradoxes that link to management learning frameworks or concepts, then frameworks from non-learning fields such as institutional logics and innovation strategy.

\section{How to manage family business paradoxes: a) paradoxes from management learning frameworks}

Garcia et al. (2019) present a pathway through Litz's (2012) paradox of conformity vs. non-conformity. If they are to persuade next-generation members to join the family firm, parents must embrace the classic 'roots and wings' paradox, simultaneously imbuing in their offspring a feeling of belonging and the confidence to fly independently. Deep roots without wings cause a lack of self-confidence that binds nextgeneration members to the family firm (Sharma and Irving 2005). But equally, strong wings with shallow roots encourage them to fly away from their family firm (Sieger et al. 2016). The roots and wings paradox resonates with L1: successors must go outside yet appreciate the special qualities of the family firm enough to return. Garcia et al. (2019) theorize the indirect influence of perceived parental support ('wings') and psychological control ('roots') on next-generation engagement through the mediating variables of selfefficacy and commitment to the family business. Dhaenens et al. (2019) suggest that mentoring, particularly by a family member, produces the necessary affective commitment (the mediator of Garcia et al.'s psychological control) and sometimes even normative and continuance commitment. Mentoring helps potential leaders move from L2 to L3 by increasing their willingness and competence to lead the family firm. In addition, successors are likely to be attached to a family business mentor when they go outside as part of L1 Learning business, preparing them for L2 Learning our business.

The 'chaos creates continuity' paradox Comparatively few researchers explicitly discuss paradox in successor learning, but there is evidence of the informal, even chaotic way family business management is learned that supports Moores and Barrett's (2002) findings that the process is highly paradoxical. Konopaski et al.'s (2015) study of 18 respondents from Canadian family businesses shows how continuity is created by chaos. Continuity involves balancing tradition and change through a learning process that is uneven, nonlinear, and unpredictable. Despite this, dealing with one problem after another by combining past and present knowledge creates continuity: a clarifying pathway which enables family members to cope with a welter of prevailing paradoxes. Continuity is achieved by 'continuing differently' at L2 and 'informal formality' at L3: professionalizing the firm while preserving the informality of family co-participation.

The paradox of formal international business education While much L2/L3 learning inside the family business could be expected to be chaotic and subject to paradox, one would expect formal, international study of business outside the family (recommended in L1), to be less paradoxical. Firm owners often 'nudge' their offspring to study in fields relevant to the family firm, hoping they will equip themselves with relevant technical skills (Jaskiewicz et al. 2015). It is common in Korean, Singaporean-Chinese, Taiwanese, and PR China firms that aspiring successors undertake formal business training overseas, not necessarily in Western universities alone. Korean chaebol owners have sent their offspring to prestigious Japanese universities due to the colonial, economic, and cultural links with Korea's former colonizer (Tsui-Auch and Lee 2003). Zhao et al. (2018) explored the extent to which the international education of successors of publicly-listed family firms in PR China, a transitional economy, equips them with a different cognitive outlook compared with their predecessors, and whether international education influences the level of strategic change - important in a transitional economy - in a post-succession firm.

They found that strategic change was likely following succession, and that successors with international education undertook greater strategic change than those without. Few founders had any international education experience in contrast to most successors. Of these, some had graduated from elite universities and others from lower status institutions. Strategic deviation in post-succession firms was significantly positive when the successor had received education from a foreign elite university, but successors with an elite domestic (i.e., Chinese) university or general university experience abroad made less adventurous strategic choices. Thus less well-educated successors appear more conservative and more cognitively embedded in local kinship networks than their nominally better educated counterparts. There was a significantly negative relationship between strategic change and financial performance in the two years 
following succession, echoing findings in OECD contexts that founder-managed firms frequently outperform family successor-managed firms (Bennedsen et al. 2007; Carney et al. 2015). This might have been because two years was not long enough to determine the eventual effects of strategic changes, or a result of the continuing influence of founder strategies. In addition, some senior executives are overconfident (Engelen et al. 2015; Li and Tang 2010) which, especially when combined with undue optimism, lowers firm revenue growth in contexts of high environmental dynamism and is associated with higher firm failure rates (Hmieleski and Baron 2009).

Most importantly from a 4Ls perspective, elite, internationally-educated successors may become relationally disembedded from valuable local networks (Chung and Luo 2013), which are vital assets in transitional and emerging economies (Luo et al. 2012). Zhao et al. (2018:21/28) warn against 'essentializing tendencies in much family firm research: perspectives such as agency theory and SEW [which] often overlook the effects of the cultural and institutional context on family firm behavior.' Less wealthy Chinese successors, including those in rural areas, increasingly use online business training resources to supplement their informal learning (Ren and Zhu 2017). This would prevent international business training from interrupting relational, on-the-job business learning. It would be paradoxical if Chinese successors to top firms, through elite international training, actually ran more risk of disrupted learning than their counterparts in China and elsewhere. Zhao et al.'s results remind us that the 4Ls model should be used with due attention to the cultural and institutional environment.

The 'training reduces learning' paradox Blanco-Mazagatos et al. (2019, forthcoming) examine formal human resource (HR) practices in family firms, both skill-enhancing (e.g., firm entry requirements, training programs) and motivation-enhancing (e.g., internal promotion systems, compensation and incentive plans). They wanted to know whether the two types of practices differentially affected family and nonfamily employees' organizational human capital (OHC). Their study of 707 unlisted Spanish family firms showed that skill and motivation practices enhanced the OHC of both types of employee. However only motivation-enhancing practices, not skill-enhancing practices, continue to enhance family employees' $\mathrm{OHC}$ over successive generations. The authors posit that in a family firm's early development, family members are motivated to obtain skills to further family goals even without skill-enhancing or motivation-enhancing practices. With succeeding generations, however, entering the family firm becomes more competitive amongst family members, because there are more of them and because the firm does not need to hire them all. This makes skill-enhancing practices attractive to family members but only until they enter the firm. After that, the easier criteria for compensation or promotion for family employees compared to nonfamily employees, mean family employees tend to receive these benefits without acquiring further skills. The effect of motivation-enhancing practices for family employees is not eroded over the generations in this way.

The study reinforces the value of the formal motivation and skill-enhancing HR practices that, according to the $4 \mathrm{Ls}$, are part of $\mathrm{L} 3$ professionalization. However, unless the firm avoids bifurcation bias, that is, treating nonfamily employees less favorably than family employees, skill-enhancing practices will be less effective with family employees than with non-family employees, particularly over successive generations. If formal entry requirements also apply to potential successors, formal HR practices strengthen the 4Ls norm that leaders gain business and personal proficiencies (for which they 'go outside') before they take their first 'inside' role.

The family vs. human capital paradox Ahrens et al. (2019) touch on successor learning via an investigation of the impact of human capital on post-succession firm performance. They examined the apparent contradiction between empirical findings that predominantly document inferior performance of family CEOs post-succession, and the theoretical literature that predicts positive effects of family involvement. In their study of post-succession performance in 804 German family firms of between 30 and 1,000 employees, they disentangled the 'family member' attribute of the CEO from other attributes such as CEOrelated human capital. Factors positively linked with post-succession firm performance included the CEO's business education, industry experience, age (a proxy for general experience), leadership experience, and use of a business plan during the succession. Furthermore, successors who rejected the status quo had better post-succession firm performance. Their results support the idea that family business leaders whose firms perform well post-succession follow the 4Ls development trajectory, particularly L1 to L3. Acquiring business-related knowledge through outside experience coincides with the L1 priority. Identifying familymember attributes that grant access to specific knowledge, values, identity, and vision is consonant with 
L2. The finding that firms whose successors reject the status quo perform better suggests that successful family successors not only learn from prior generations but continue the firm differently.

Two recent empirical studies of family social capital (FSC), Sanchez et al. (2019) and Herrero and Hughes (2019, forthcoming), investigated its paradoxical nature (Irava and Moores 2010), that is, its capacity to have both positive and negative effects. Family social capital refers to the 'internal bonding' resources available through family linkages (Habbershon and Williams 1999; Arrègle et al. 2007). Both studies looked at the differential impact on firm performance (economic and non-economic outcomes in Sanchez et al. and financial outcomes in Herrero and Hughes) of Nahapiet and Ghoshal's (1998) three dimensions of FSC: structural FSC (reflecting the strength of family ties and members' information-sharing); relational FSC (the degree of commitment, trust, and identity among family firm members); and cognitive FSC (members' shared representations, interpretations, purpose, and meaning).

Using configuration analyses of two large samples of U.S. family firms, Sanchez et al. (2019) found three clusters of family firms: firms with Instrumental (high), Identifiable (moderately low), and Indistinguishable (low) FSC. Successors in firms with the highest level of FSC (i.e., Instrumental) had significantly enhanced outside experience compared with successors in firms with lower FSC (i.e., Identifiable or Indistinguishable). The Instrumental FSC cluster had the highest levels of all three types of FSC, but had less structural FSC than cognitive and relational FSC. The value of FSC seems to lie primarily in its relational and cognitive dimensions. Herrero and Hughes (2019, forthcoming) support this tentative conclusion. They examined the effect of the three dimensions of social capital on the ROE of Spanish family firms in the manufacturing sector. Relational and cognitive FSC significantly enhanced family firm financial performance, but structural FSC increased financial performance only up to a threshold, then decreased it.

These findings resonate with the 4Ls. At high levels, structural FSC can trap the family firm in its established networks, blocking the entry of new knowledge. To counter this, potential leaders need to go outside (L1), and/or their leadership preparation must include outside networks. Moreover, the positive effect of relationship FSC reinforces the pathway through L3: 'informal formality', i.e., informal practices that promote family-based trust and communication. Finally, the positive relationship between cognitive FSC and firm performance is consistent with L2: 'valuing values' of the family business and family members' shared understandings.

The 'manage chaos with simplicity' paradox This is the obverse of the chaos creates continuity paradox. Pieper et al. (2015) examine a salient source of family firm complexity, even chaos: the presence of at least two unrelated founding families. If combining one family with business adds management complexity, we would expect firms run by two or more unrelated families to be even more complicated. The authors studied five multi-family businesses of between 200 and 5,000 employees which had persisted for two, three, or four generations. Instead of managing complex problems through complex structures and processes, the firms used simple rules imprinted by the founders. The simple rules related to executive formation and decision-making boundaries. Executive formation comprised two principles: a) family member skills (via extensive outside experience or working one's way up from the bottom to divisional leadership), and b) openness to outsiders as leaders. The decision-making boundaries rule meant broad decision parameters, not detailed planning or reliance on consultants. In 4Ls terms, the executive formation rule reflects commitment to developing successor competence in L1, L2 and L3. Requiring family members to have either extensive outside experience or division-level leadership experience echoes the L1 pathway: 'go outside'. Only division-level internal experience, which would require external networks, can replace outside learning. 'Staying open to outsiders as leaders' also brings external knowledge into the firm. Finally, 'broad parameters, not detailed planning' echoes L2: pass on principles and philosophies, not the details.

The 'innovation through tradition' paradox Erdogan et al.'s (2019) study of eight long-lived Turkish family firms found four ways to manage the 'willingness vs. ability to innovate' paradox. The legacy of previous family generations imprints two different approaches to both tradition and innovation. The preservation approach to tradition denotes firms where the family is committed to the founder's values, beliefs, and craftsmanship. Conversely, the revival approach to tradition characterizes firms where some elements of familial tradition have faded over time. Regretting this, firms recover past elements to revive tradition. Concerning innovation, firms may adopt a segregation approach, distinguishing iconic products from new products and processes, or an integration approach, protecting the essence and reinterpreting traditional products through innovation. All four approaches resonate with our L2 pathway: keep the philosophies and principles (i.e., maintain tradition), but innovate by discarding outdated detail. 
The 'perpetuating values damages the firm' paradox Kidwell et al. (2018) also focus on the 'imprinting' process: passing values from earlier generations to later ones. However they sound a darker note. Drawing attention to the halo effect around organizational learning, the authors argue that excessive parental altruism and early imprinting of values of such as entitlement and a sense of injustice create negative, damaging behaviors. This reveals a gap in the 4Ls: we, like many researchers, tended to overlook the downside of learning organizations and perpetuating values.

\section{How to manage family business paradoxes: b) paradoxes from institutional theory and innovation strategy}

The 'what' paradoxes of family business include willingness vs. ability to innovate. Mazzelli et al. (2018), working from an institutional theory perspective (DiMaggio and Powell 1983; Meyer and Rowan 1977; Scott 1987), present ways of managing this paradox which are themselves paradoxical. Their study of the product innovations of Spanish manufacturing firms between 1998 and 2012 found, unexpectedly, that family firms showed higher levels of innovation output than nonfamily firms when the decision to introduce new products was perceived as socially desirable, that is, when their peers were doing the same. Family firms' desire to preserve social wealth leads them to follow this 'conformity-in-distinctiveness' rationale, in contrast to nonfamily firms which seek positive recognition from 'distinctiveness-inconformity'. Paradoxically then, the desire to conform to norms fuels innovation in family firms.

Other articles positing ways to manage the ability vs. willingness to innovate paradox include Gómez-Mejía et al. (2016) who challenge the assertion that family firms are risk-averse. They reframe the concept of wealth to include socio-economic wealth (SEW), a frequent feature of family firms. To preserve SEW, family firms may be risk-willing and risk-averse at the same time. Their study of 1,237 family-owned olive oil mills in southern Spain confirmed avoidance of SEW as these firms' primary reference point. To avoid such losses, family firms accept a significant risk to their performance, yet simultaneously avoid risky decisions that might aggravate that risk. This study confirms the L2 pathway: keep the philosophies and discard detail.

The successor commitment or successor competence paradox Richards et al. (2019) use institutional theory to explore another type of 'ability vs. willingness' paradox for incumbents: finding a family successor who is both highly committed and highly competent. Commitment to continuing the family business is limited because a career in family firm leadership competes with other attractive options outside. Equally, not all potential successors are equally competent. Finding a family member who meets both requirements is often difficult, requiring the incumbent to compromise. Richards et al. (2019) examined reactions from 1,060 family firm incumbents to a case vignette to see whether their relative exposure to two different institutional logics, family logic (indicated by the number of family members in their firm's management and the value their country of origin places on family) and business logic (indicated by the duration of their outside professional experience and education level), shifted their preference for a successor lacking either high competence or high commitment. The vignette manipulated firm performance: half the incumbents imagined that their firm was performing below the industry average and half that it was performing above average.

A priori, incumbents preferred a family successor but had no clear preference between competent and committed successors. However their relative exposure to family or business institutional logic and their perceptions of higher or lower firm performance shifted their preference towards a highly competent successor (incumbents with higher 'corporate' institutional accessibility and low firm performance) and a highly committed successor (incumbents with higher 'family' institutional accessibility and high firm performance). Results for cultural embeddedness were not clear-cut, but appeared influential. Incumbents from Italy, which places strong value on family, would not forgo benefits from competence, but preferred a committed successor much more than incumbents from French-speaking regions, where familial preferences are lower. The successor commitment or competence paradox echoes the L1 paradox: going outside may turn into an attractive career which means the successor never returns. Our L1 pathway - go outside anyway - focused on the successor. Richards et al. broaden this by examining the incumbent's view of the L1 paradox.

Research focused on hybrid organizations and industries suggests still other explanations of how family firms manage the paradoxical outcomes of competing institutional logics. For example, Yan et al. (2019) examine socially responsible investing (SRI) in the Asian financial sector, particularly how financial logic 
both provides the means to found novel, socially responsible financial ventures, and enforces profitmaximizing financial ends. The outcome is that the founding of SRI funds has a curvilinear, inverted Ushaped relationship with the prevalence of financial logic in society. Alternative logics - those of unions, religion, and green political parties - moderate these effects. By applying the 4Ls with due attention to prevailing cultural and institutional logics, future researchers could examine how shifts in the strength of financial institutional logic affect how leaders shape family firm goals over time, e.g., regarding the balance between economic and socio-emotional wealth.

De Massis et al. (2015) developed the Family-Driven Innovation (FDI) framework, highlighting the need for consistency between a family firm's idiosyncrasies and its innovation strategies. Paradox is apparent in that the family firm's idiosyncrasies yield continuity in the form of innovation strategies. Osnes et al. (2016) also consider how paradox generates strategies. They consider a range of choices arising from the ability vs. willingness to innovate and founder control vs. successor autonomy paradoxes: safety or loss of attachments, a stable notion of self or grasping new opportunity, own drive or dependency on others. Using interviews with family members and nonfamily employees of firms in a range of countries, they show how strategy formations such as succession, cluster ownership, stewardship, and new business models are negotiated.

\section{Pathways to further research: Extending the 4Ls model}

Our literature review shows that the 4Ls are confirmed by or at least resonate with many family business debates and findings. The 'how' paradoxes, in contrast to the 'what' paradoxes, are not reducible to a small number of basic paradoxes. They echo our insights into the paradoxical aspects managing family firms and point out new ones. Some broadly confirmatory findings nevertheless suggest modifications to the original 4Ls. Pieper et al.'s finding that holding a divisional leadership role can offset lack of external experience, and Ahrens et al.'s finding that both external and internal experience enhance family CEO-led postsuccession firm performance indicate that the L1 pathway needs expanding. 'Go outside' could be partially replaced by developing outside networks (Cabrera-Suárez 2018). However relying on family networks (structural FSC) alone to source outside knowledge is inadequate (Sanchez et al. 2019; Herrero and Hughes 2019).

Our literature review results also suggest how the 4Ls model might be extended. One kind of extension to a model or theory arises when revisiting its components suggests their potential might not have been fully exploited. Another type arises when a model points beyond its primary construct (here, how family business leadership is learned) to suggest linkages with other areas, frameworks or issues that are strictly 'outside' it, but lie adjacent to its domain. Linking the model with adjacent frameworks may suggest new, mutually informative research questions, advancing the conceptual development of both models, or suggesting ways to test them empirically. Yet another way is to consider possible modifications required by different cultural or institutional environments. We do all of these in the following sections.

\section{Looking inside the $4 \mathrm{Ls}^{3}$}

Learning between phases In the 4Ls, successors encounter a specific paradox within each of the model's four developmental quadrants and learn to manage it. Thus the 4Ls model implicitly locates successor learning only within the four phases; the arrows in Figure 1 point simply to the theoretical sequence in which successors can be expected to encounter and learn to manage a specific paradox. However Table 1 suggests that learning also happens between successive developmental phases. Enabling innovative action suggests moving from merely acknowledging tradition (L2) and the need for change (L1) towards implementing paradoxical strategies at L3. At L3 the leader exercises 'informal formality', maintaining informal family controls while establishing the formal controls needed in contemporary contexts. The Family Liquidity vs. Business Growth paradox may also appear when the leader moves between L2 and L3 and a similar 'both/and' approach is needed. While reinvesting profits (through equity rather than debt) enables more aggressive growth, leaders must also accommodate some family members' needs to receive dividends. Finally, family business leaders often struggle to move between L3 Learning to lead and L4 Learning

\footnotetext{
${ }^{3}$ We would like to acknowledge the contribution of Justin Craig to developments of the 4Ls model in the many years of teaching the model to students the world over.
} 
to let go. Founder Control vs. Successor Autonomy tensions are played out when leaders stay (that is, fail to go) and inhibit the next generation's autonomy.

Specific examples of learning pathways between, not only within, the 4Ls phases include Mitchell et al. (2009) who developed the construct of successor discretion to test how likely successors were to exercise 'entrepreneurial agency' following succession. Their results present a pathway through Founder Control vs. Successor Autonomy. Specific successor characteristics: tolerance of ambiguity, locus of control, cognitive complexity, professional aspiration, power base, and political acumen increase their discretion, whereas a successor's commitment to an existing course of action or a former incumbent's attempts to maintain control hinder it. Business factors, including wealth preservation-based inertia and familiness, that is, the unique bundle of firm capabilities and resources created by family involvement (Habbershon and Williams 1999). Familiness is paradoxical: it can affect the firm both positively and negatively (Irava and Moores 2010). According to Mitchell et al. (2009), preservation-based inertia and familiness reduce successor discretion and heighten the negative effect of successor commitment. In line with its paradoxical nature, however, familiness could be expected also to increase successor discretion by magnifying the positive effect of a successor's political acumen. We could test both Mitchell's propositions and the 4Ls model by investigating whether a successor who had developed confidence, self-efficacy, and legitimacy as a result of going outside the firm (L1) and/or previous senior-level involvement in it (Ahrens et al. 2019), has higher successor discretion, evidenced in their undertaking more adventurous strategic change (Zhao et al. 2018) following succession.

Combining learning phases Combining learning phases into larger units also yields new insights and questions. Consider Figure 1 again. Combining L1 Learning business with L2 Learning our business suggests an Apprenticeship learning phase. Cognitive apprenticeship theorists (e.g., Merton et al. 1957; Bragg 1976) refer to socialization as a process of acquiring skills and values relevant to one's society or profession. Combining the long-term focus common to L3 Learning to lead our business (ensuring business longevity) and L4 Learning to leave our business (passing a viable business to a competent, committed successor), suggests a Stewardship phase. Much has been written about family business stewardship (see reviews by Madison et al. 2016 and Chrisman 2019) but less about apprenticeship. An exception is Le Breton-Miller and Miller (2015) who show how apprenticeship learning lays the foundation for stewardship. In 4Ls terms, [L1 + L2] $\rightarrow$ [L3 + L4].

Another way to combine the elements of the $4 \mathrm{Ls}$ is to consider what all four mean cumulatively. Theories of expertise and its acquisition have been developed in fields from sports to creative arts to medicine (Simonton 2014; Lewandowsky and Thomas 2009). We know, for example, that experts are better problem solvers than novices because they hold a large amount of organized domain knowledge that reflects deep understanding. Experts organize their knowledge around core components, in contrast to novices who organize knowledge as a list of facts, formulas, or heuristics. The expertise acquisition literature suggests that progressing through the $4 \mathrm{Ls}, \mathrm{L} 1 \rightarrow \mathrm{L} 2 \rightarrow \mathrm{L} 3 \rightarrow \mathrm{L} 4$, is like attaining expert-level understanding. For example, novices (at L1 and to some extent L2) rely on lists of facts and textbook heuristics and often display anchoring biases in their efforts to master the information that their Inquisitive but laborious searches unearth. Experts (L3/L4) develop through progressive problem solving and experiential learning, eventually enabling very fast decisions that proceed from expert Intuitions. Between these two extremes (L1/novices and L3-L4/experts), successors develop Insights and apply them via Innovative processes (e.g. by 'continuing differently' and implementing change through 'informal formality'). Figure 2 illustrates the extensions to the 4 Ls that arise from combining its elements in new ways.

\section{Place Figure 2 about here.}

However, even experts are subject to error, e.g., through contextual effects and other sources of cognitive bias (Dror et al. 2006). The benefits of expertise are less pronounced when solving problems with higher initial structure (Spence and Brucks 1997). Experts make some types of error more than novices when factors that supported their expertise, such as good eyesight, decline (Dror et al. 2006). The expertise literature suggests many analogous research questions to extend the 4Ls. For example, we could ask what types of contextual bias reduce incumbents' expert intuitions and insights, what prompts incumbents to reduce their involvement in day-to-day firm tasks, and what business problem structures benefit most from former incumbents' input.

\section{Looking outside the $4 \mathrm{Ls}$}


We now look outside the 4Ls, linking it with some 'adjacent' frameworks suggested by our review: effectuation and new venture creation (Sarasvathy 2001; 2009; Dew et al. 2009), bases of successor commitment (Sharma and Irving 2005), and strategic narratives (Dalpiaz et al. 2014) linked with institutional logics (Richards et al. 2019). Just as when we looked inside the 4Ls, we consider the compatibilities of these 'outside' concepts with our model and generate new research questions.

Effectuation and new venture creation For nearly 20 years Sarasvathy (2001; 2009) has examined how expert entrepreneurs think when they create new ventures. Her research has led to a new process view of entrepreneurship: effectual reasoning. Dew et al. (2009:292-293) found that the thinking processes of MBA students (novice entrepreneurs) and expert entrepreneurs (who had started two or more ventures) differed "starkly". Compared to novices, expert entrepreneurs used more effectual reasoning. Specifically, they placed more emphasis than novices on:

- Transforming means at hand into new outcomes;

- Beginning with a given set of means and focusing on generating new ends;

- Choosing projects according to what they could afford to lose;

- $\quad$ Building partnerships early;

- $\quad$ Opening themselves up to surprises.

Hayton et al. (2011) found that family firms, consistent with their reluctance to innovate, their conservative approach to debt, and the entrepreneur's embeddedness in a family, are somewhat more likely to follow effectuation processes and significantly less likely to follow causation (goal-driven) processes during new venture creation. Their new ventures are less likely than those of nonfamily firms to arise from a sudden stroke of insight, possibly reflecting the more limited knowledge available via family networks. Nevertheless, PwC's latest global market survey indicates that 25 percent of next generation family business members also started their own company (PwC 2017), and our review found many items about passing on an 'entrepreneurial legacy'. These empirical and conceptual links suggest that the 4Ls and the adjacent issue of new venture creation by family businesses are at least mutually informative. Investigating whether successors with longer outside experience (L1) use more radical strategies could test Hayton et al.'s contention that relying on family networks reduces family firms' propensity to create ventures based on new insights.

Bases of successor commitment Sharma and Irving (2005), in an influential conceptual paper, posit four commitment 'mindsets' which prompt people to join their family businesses, namely:

- Affective commitment: Individuals perceive an alignment between family business opportunities and their personal identities and career interests;

- Normative commitment: Individuals feel obliged to join the family firm out of a sense of loyalty;

- Calculative commitment: Individuals join to avoid perceived financial and/or social opportunity costs;

- Imperative commitment: Individuals join the family firm through a perceived lack of career alternatives.

One could investigate possible links between the bases of successor commitment and an individual's preceding or subsequent engagement with the 4Ls phases. Individuals who join their family firm out of affective commitment, i.e., a sense of personal identity and anticipated job satisfaction, could be expected to be intensely involved in the L1, L2, and L3 phases, but to have difficulty at L4, Learning to let go. Imperative commitment, by contrast, could arise from failure to engage in L1 'outside' learning. We saw earlier (via Dhaenens 2019) that having family members mentor potential successors heightens successors' leadership competence and commitment, especially affective commitment. So we could also examine how mentoring by family members produces affective commitment, and whether different types of commitment are mediated by successors' perceptions of their own competence.

Successors' strategic narratives and institutional logics Richards et al. (2019) discussed the compromise between commitment and competence the incumbent has to make if an 'ideal' successor is not available. But we also know from Dalpiaz et al. (2014) that would-be successors use specific narratives to sway the incumbent and other stakeholders in their favor. Their repertoire may include narratives aimed at changing stakeholders' perceptions of unfavourable institutional logics and firm performance. Successors' strategic use of narratives also suggests a test of the relationship between political acumen and successor discretion 
(Mitchell et al. 2009): would-be successors whose narratives changed stakeholders' views could be expected to show more political acumen; those whose narratives failed would show less. Returning to the bases of commitment, we could ask how normatively influenced but still reluctant potential successors use narratives strategically to reduce incumbents' desire to appoint them.

In Table 2 we suggest some of the many possible paradox-inspired research questions we see emerging from our 'what' and 'how' themes, especially those motivated by extensions to the $4 \mathrm{Ls}$, whether from inside the 4 Ls framework, or from 'adjacent' frameworks.

\title{
Place Table 2 about here.
}

As our literature review showed, the 4Ls align with 'how' rather than 'what' paradoxes, and this is reflected in Table 2. However the 'what' paradoxes also generate a plethora of new research questions, some arising directly from an inherent feature of family business, others focusing on how to manage them.

\section{Conclusion}

Our review and ensuing commentary followed established good practice for conducting systematic literature reviews (i.e., Tranfield et al. 2003). By adhering to these procedures and defining keywords carefully, we are confident that it encompasses the literature from 2002 to the present, and shows the progress of family firm research on family firm paradoxes since our first book. Briefly revisiting the original 4Ls reminded us of its paradoxes, priorities, and the pathways successful CEOs devised to cope with them. Subsequent conceptual and empirical research confirmed our original model of how members of family firms manage the special nature of family business and revealed some deficiencies. Both confirmations and deficiencies suggested how the 4Ls could be extended, whether by looking again at its internal components or looking outside it at adjacent frameworks and concepts. Further research questions emerged from this. We are reminded of the paradox of knowledge: the more we know, the more there is to know. We invite future researchers to join us in continuing to use paradox to critique and expand current ways of understanding the 4Ls and other models of family business, including via the research questions in this paper. Doing so will help us learn more and create more to know.

\section{References}

\section{An asterisk indicates an item discussed in the literature review results table at Appendix 1. See https://doi.org/10.6084/m9.figshare.10000553}

\author{
*Acedo-Ramirez M, Ayala-Calvo JC, and Navarrete-Martinez E (2017) Determinants of capital structure: \\ Family businesses versus Non-Family Firms. Czech Journal of Economics and Finance 67(2): 80-103. \\ Handle: RePEc:fau:fauart:v:67:y:2017:i:2:p:80-103 \\ *Acosta-Prado JC, Longo-Somoza M, Lozano-Garcia, MB (2017) Does family ownership affect innovation \\ activity? A focus on the biotechnological industry. Innovar 27(65): pp. 11-23. \\ https://doi.org/10.15446/innovar.v27n65.64886
}

\begin{abstract}
*Agyapong A, Ellis F, and Domeher D (2016) Competitive strategy and performance of family businesses: Moderating effect of managerial and innovative capabilities. Journal of Small Business \& Entrepreneurship, 28(6): 449-477. http://dx.doi.org/10.1080/08276331.2016.1217727
\end{abstract}

*Ahrens J-P, Calabrò A, Huybrechts J, and Woywode M (2019, forthcoming) The enigma of the family successor-firm performance relationship: A methodological reflection and reconciliation attempt. Entrepreneurship Theory and Practice. http://dx.doi.org/10.1177/1042258718816290

*Akbar M (2008). Do the governance, strategic and organisational practices differ in Indian family and professionally managed firms? Vision 12(3): 15-30. https://doi.org/10.1177/097226290801200302 
*Almodóvar P, Verbeke A, and Rodríguez-Ruiz Ó (2016) The Internationalization of Small and MediumSized Family Enterprises: The Role of Human Asset Quality. Journal of Leadership \& Organizational Studies 23(2): 162-174. https://doi.org/10.1177/1548051816633066

Arrègle JL, Hitt MA, Sirmon DG, and Very P (2007) The development of organizational social capital: Attributes of family firms. Journal of Management Studies 44(1): 73-95. https://doi.org/10.1111/j.1467$\underline{6486.2007 .00665 . x}$

*Arslan-Ayaydin Ö, Barnum D, Mehmet BK, and Özdemir H (2014) How is moral hazard related to financing R\&D and innovations? European Research Studies Journal 17(4): 111-131. https://www.um.edu.mt/library/oar/handle/123456789/30729

*Arzubiaga U, Maseda A, Iturralde A, and Iturralde T (2019) Exploratory and exploitative innovation in family businesses: the moderating role of the family firm image and family involvement in top management. Review of Managerial Science 13(1): 1-31. https://doi.org/10.1177/0312896218780949

*Bammens Y, Voordeckers W, and Van Gils A (2008) Boards of directors in family firms: A generational perspective. Small Business Economics 31(2): 163-180. https://www.jstor.org/stable/40650937

*Banalieva ER and Eddleston KA (2011) Home-region focus and performance of family firms: The role of family vs. non-family leaders. Journal of International Business Studies 42(8): 1060-1072.

https://doi.org/10.1057/jibs.2011.28

*Barbera F and Hasso T (2013) Do we need to use an accountant? The sales growth and survival benefits to family SMEs. Family Business Review 26(3): 271-292. https://doi.org/10.1177/0894486513487198

*Barrett M and Moores K (2009) Spotlights and shadows: Preliminary findings about the experiences of women in family business leadership roles. Journal of Management and Organization 15(3): 363-377. https://doi.org/10.1017/S1833367200002674

*Barrett M and Moores K (2009) Women in Family Business Leadership Roles: Daughters on the Stage. Cheltenham UK and Northampton MA: Edward Elgar.

https://research.bond.edu.au/en/publications/women-in-family-business-leadership-roles-daughterson-the-stage

*Basco R and Rodríguez MJ (2009) Studying the family enterprise holistically: Evidence for integrated family and business systems. Family Business Review 22(1): 82-95.

https://doi.org/10.1177/0894486508327824

Baù M, Chirico F, Pittino D, Backman M, and Klaesson J (2019) Roots to grow: Family firms and local embeddedness in rural and urban contexts. Entrepreneurship Theory and Practice 43(2): 360-385. https://doi.org/10.1177/1042258718796089

*Bchini B (2014) Entrepreneurship: A key to minimizing the risks of Tunisian family businesses. Journal of Business Studies Quarterly 5(4): 68-80. ProQuest document ID1542023408.

Bennedsen M, Nielsen KM, Perez-Gonzalez F, and Wolfenzon, D (2007) Inside the family firm: The role of families in succession decisions and performance. The Quarterly Journal of Economics 122(2): 647-691. https://doi.org/10.1162/qjec.122.2.647

*Berger R, Lamond D, Gavish Y, and Herstein, R (2016) The evolution of management from a trust to arm's length model in family run businesses: The case of the diamond industry. Journal of Management History 22(3): 341-362. https://doi.org/10.1108/JMH-03-2016-0012

*Berent-Braun MM and Uhlaner LM (2012) Family governance practices and teambuilding: Paradox of the enterprising family. Small Business Economics 38: 103-119. https://doi.org/10.1007/s11187-010$\underline{9269-4}$ 
*Bjuggren P and Sund L (2005) Organization of transfers of small and medium-sized enterprises within the family: Tax law considerations. Family Business Review 18(4): 305-319.

https://doi.org/10.1111/j.1741-6248.2005.00050.x

*Blanco-Mazagatos V, de Quevedo-Puente E, and Delgado-García JB (2017) Human resource practices and organizational human capital in the family firm: The effect of generational stage. Journal of Business Research 84(C): 337-348. http://dx.doi.org/10.1016/i.jbusres.2017.09.017

*Boers B (2013) Organizational identity construction in family businesses: A dualities perspective. JIBS Dissertation Series No. 091, Jönköping International Business School. http://www.divaportal.org/smash/get/diva2:643530/FULLTEXT01.pdf

Booth A, Sutton A, and Papaioannou D (2012) Systematic approaches to a successful literature review. London: Sage.

*Bornhäll A, Johansson D, and Palmberg J (2016) The capital constraint paradox in micro and small family and nonfamily firms. Journal of Entrepreneurship and Public Policy 5(1): 38-62.

https://doi.org/10.1186/2192-5372-2-14

*Boubaker S, Derouiche I, and Hassen M (2015) Family control and the value of cash holdings. Journal of Applied Business Research 31(2): 647-660. https://doi.org/10.19030/jabr.v31i2.9159

Bragg AK (1976) The socialization process in higher education. Washington, DC: The American Association of Higher Education. https://eric.ed.gov/?id=ED132909

*Brinkerink J (2018) Broad search, deep search, and the absorptive capacity performance of family and nonfamily firm R\&D. Family Business Review 31(3): 295-317.

https://doi.org/10.1177/0894486518775187

*Broekaert W, Andries P, and Debackere K (2016) Innovation processes in family firms: The relevance of organizational flexibility. Small Business Economics 47(3): 771-785. https://doi.org/10.1007/s11187$\underline{016-9760-7}$

Cabrera-Suárez MK, García-Almeida DJ, and De Saá-Pérez P (2018) A dynamic network model of the successor's knowledge construction from the resource- and knowledge-based view of the family firm. Family Business Review 31(2): 178-197. https://doi.org/10.1177/0894486518776550

*Calabrò A and Mussolino D (2013) How do boards of directors contribute to family SME export intensity? The role of formal and informal governance mechanisms. Journal of Management \& Governance 17(2): 363-403. https://doi.org/10.1007/s10997-011-9180-7

*Campbell DJ (2001) The proactive employee: Managing workplace initiative. Academy of Management Executive 14(3): 52-66. https://doi.org/10.5465/ame.2000.4468066

*Capello C (2015) Family, social capital and internal migration in Italy: The case of the people of Tramonti. Human Affairs: Postdisciplinary Humanities \& Social Sciences Quarterly 25(1): 40-57. https://doi.org/10.1515/humaff-2015-0004

Carney M (2005) Corporate governance and competitive advantage in family-controlled firms. Entrepreneurship Theory and Practice, 29(3): 249-265 2005.

https://doi.org/10.1111/j.1540-6520.2005.00081.x

*Carney M (2007) Minority family business in emerging markets: Organization forms and competitive advantage. Family Business Review 20(4): 289-300. http://doi.org/10.1111/j.1741-6248.2007.00097.x

Carney M, Van Essen M, Gedajlovic ER, and Heugens PPMAR (2015) What do we know about private family firms? A meta-analytical review. Entrepreneurship Theory and Practice, 39(3), 513-544.

https://doi.org/10.1111/etap.12054 
*Casprini E, De Massis A, Di Minin A, Frattini F, and Piccaluga A (2017) How family firms execute open innovation strategies: The Loccioni case. Journal of Knowledge Management 21(6): 1459-1485.

https://doi.org/10.1108/JKM-11-2016-0515

*Cerrato D and Piva M (2012) The internationalization of small and medium-sized enterprises: The effect of family management human capital and foreign ownership. Journal of Management \& Governance 16(4): 617-644. https://doi.org/10.1007/s10997-010-9166-x

*Chirico F, Gómez-Mejía LR, Hellerstedt K, Withers M, and Nordqvist M (2019) To merge, sell, or liquidate? Socioemotional wealth, family control, and the choice of business exit. Journal of Management. http://dx.doi.org/10.1177/0149206318818723

*Chirico F, Nordqvist M, Colombo G, and Mollona E (2012) Simulating dynamic capabilities and value creation in family firms: Is paternalism an 'asset' or a 'liability'? Family Business Review 25(3): 318-338. https://doi.org/10.1177/0894486511426284

*Chrisman JJ, Chua JH, De Massis A, Frattini F, and Wright, M (2015) The ability and willingness paradox in family firm innovation. Journal of Product Innovation Management 32(3): 310-318.

https://doi.org/10.1111/ipim.12207

Chrisman JJ, Chua JH, De Massis A, Minola M, and Vismara S (2016) Management processes and strategy execution in family firms: From 'What' to 'How'. Small Business Economics 47(3): 719-734.

https://doi.org/10.1007/s11187-016-9772-3

Chrisman JJ (2019, forthcoming) Stewardship theory: Realism, relevance, and family firm governance. Entrepreneurship Theory and Practice. http://dx.doi.org/10.1177/1042258719838472

Chua JH, Chrisman JJ, and Sharma P (1999) Defining the family business by behavior. Entrepreneurship Theory and Practice 23(4): 19-39. https://doi.org/10.1177/104225879902300402

*Ciravegna L, Kano L, Rattalino F, and Verbeke, A (2019, forthcoming) Corporate diplomacy and family firm longevity. Entrepreneurship Theory and Practice. https://doi.org/10.1177/1042258719838477

*Cirillo A, Romano M, and Ardovino O (2015) Does family involvement foster IPO value? Empirical analysis on Italian stock market. Management Decision 53(5): 1125-1154.

https://doi.org/10.1108/MD-11-2014-0639

*Classen CAE and Schulte R (2017) How do conflicts impact change in family businesses? The family system and familiness as a catalytic converter of change. Journal of Organizational Change Management 30(7): 1198-1212. https://doi.org/10.1108/JOCM-04-2016-0071

*Craig J and Moores K (2005) Balanced scorecards to drive the strategic planning of family firms. Family Business Review 18(2): 105-122. https://doi.org/10.1111/j.1741-6248.2005.00035.x

*Craig JB and Salvato C (2011) The distinctiveness, design, and direction of family business research. Family Business Review 25(1): 109-116. https://doi.org/10.1177/0894486511429682

*Cui V, Ding S, Liu M, and Wu, Z (2018) Revisiting the effect of family involvement on corporate social responsibility: A behavioral agency perspective. Journal of Business Ethics 152(1): 291-309. https://doi.org/10.1007/s10551-016-3309-1

*Dale MC, Shepherd D, and Woods C (2008) Family models as a framework for employment relations in entrepreneurial family businesses. New Zealand Journal of Employment Relations (Online) 33(1): 55-73. https://doi.org/10.1057/jibs.2011.28

*Dalpiaz E, Tracey P, and Phillips NW (2014) Succession narratives in family business: The case of Alessi. Entrepreneurship Theory and Practice 38(6): 1375-1394. https://doi.org/10.1111/etap.12129 
*Decker C and Günther C (2017) The impact of family ownership on innovation: evidence from the German machine tool industry. Small Business Economics 48(1): 199-212.

https://doi.org/10.1007/s11187-016-9775-0

*De Massis A, Kotlar J, Chua JH, and Chrisman JJ, (2014) Ability and willingness as sufficiency conditions for family-oriented particularistic behavior: Implications for theory and empirical studies. Journal of Small Business Management 52(2): 344-364. https://doi.org/10.1111/jsbm.12102

*De Massis A, Di Minin A, and Frattini F (2015) Family driven innovation: Resolving the paradox in family firms. California Management Review 58(1): 5-19. https://doi.org/10.1525/cmr.2015.58.1.5

Dew N, Read S, Sarasvathy SD, and Wiltbank R (2009) Effectual versus predictive logics in entrepreneurial decision-making: Differences between experts and novices. Journal of Business Venturing 24: 287-309. https://doi.org/10.1016/j.jbusvent.2008.02.002

DiMaggio PJ and Powell WW (1983) The iron cage revisited: Institutional isomorphism and collective rationality in organizational fields. American Sociological Review 48(2): 147-160. https://doi.org/10.2307/2095101

*Ding S, Qu B, and Wu Z (2016) Family control, socioemotional wealth, and governance environment: The case of bribes. Journal of Business Ethics 136: 639-654. http://dx.doi.org/10.1007/s10551-015-2538-z

*Dhaenens AJ, Marler LE, Vardaman JM, and Chrisman JJ (2018) Mentoring in family businesses: Toward an understanding of commitment outcomes. Human Resource Management Review 28(1): 46-55. https://doi.org/10.1016/j.hrmr.2017.05.005

*Dodd SD and Dyck, B (2015) Agency, stewardship, and the universal-family firm: A qualitative historical analysis. Family Business Review 28(4): 312-331. https://doi.org/10.1177/0894486515600860

Dror IE, Charlton D, and Péron AE (2006) Contextual information renders experts vulnerable to making erroneous identifications. Forensic Science International 156(1): 74-78.

https://doi.org/10.1016/j.forsciint.2005.10.017

*Duarte Alonso A, Kok S, and O’Shea M (2018) Family businesses and adaptation: A dynamic capabilities approach. Journal of Family and Economic Issues 39(4): 683-698.

https://doi.org/10.1007/s10834-018-9586-3

*Duran, P., Kammerlander, N., Van Essen, M., \& Zellweger, T. (2016). Doing more with less: Innovation input and output in family firms. Academy of Management Journal, 59(4): 1224-1264.

https://doi.org/10.5465/amj.2014.0424

*Eddleston K, Jaskiewicz P, and Wright M (2019) Family firms and internationalization in the Asia-Pacific: The need for multi-level perspectives. Asia Pacific Journal of Management (Jun): 1-17.

https://doi.org/10.1007/s10490-018-9608-6

*Eddleston KA, Otondo RF, and Kellermanns FW (2008) Conflict participative decision-making and generational ownership dispersion: A multilevel analysis. Journal of Small Business Management 46(3): 456-484. https://doi.org/10.1111/j.1540-627X.2008.00252.X

*Ensley M (2006) Family businesses can out-compete: As long as they are willing to question the chosen path. Entrepreneurship Theory and Practice 30(6): 747-754. https://doi.org/10.1111/j.1540$\underline{6520.2006 .00148 . x}$

Engelen A, Neumann C, and Schwens C (2015) "Of course I can": The effect of CEO overconfidence on entrepreneurially oriented firms. Entrepreneurship Theory and Practice, 39(5): 1137-1160.

https://doi.org/10.1111/etap.12099 
*Erdogan I, Rondi E, and De Massis A (2019, forthcoming) Managing the tradition and innovation paradox in family firms: A family imprinting perspective. Entrepreneurship Theory and Practice.

http://dx.doi.org/10.1177/1042258719839712

*Fernández Z and Nieto MJ (2006) Impact of ownership on the international involvement of SMEs.

Journal of International Business Studies 37(3): 340-351. www.jstor.org/stable/3875263

*Ferreira GC and Ferreira JJM (2017) Absorptive capacity: An analysis in the context of Brazilian family firms. Mackenzie Management Review 18(1): 174-204. http://dx.doi.org/10.1590/167869712017/administracao.v18n1p174-204

Fink A (2005) Conducting research literature reviews: From the internet to paper. 2nd ed. London: Sage.

*Fuetsch E and Suess-Reyes J (2017) Research on innovation in family businesses: Are we building an ivory tower? Journal of Family Business Management 7(1): 44-92. http://dx.doi.org/10.1108/JFBM-02$\underline{2016-0003}$

*Gallucci C and D'Amato A (2013) Exploring nonlinear effects of family power on the performance of Italian wine businesses. International Journal of Wine Business Research 25(3): 185-202.

https://doi.org/10.1108/IJWBR-2012-0017

Garcia R and Calantone R (2002) A critical look at technological innovation typology and innovativeness terminology: A literature review. The Journal of Product Innovation Management 19(2): 110-132. https://doi.org/10.1111/1540-5885.1920110

*Garcia PRJM, Sharma P, De Massis A, Wright M, and Scholes L (2019) Perceived parental behaviors and next-generation engagement in family firms: A social cognitive perspective. Entrepreneurship Theory and Practice 43(2): 224-243. https://doi.org/10.1177/1042258718796087

*García-Ramos R and García-Olalla M (2014) Board independence and firm performance in Southern Europe: A contextual and contingency approach. Journal of Management and Organization 20(3): 313332. https://doi.org/10.1017/jmo.2014.23

*Ghezzi S (2015) Familism as a context for entrepreneurship in northern Italy. Postdisciplinary Humanities \& Social Sciences Quarterly 25(1): 58-70. https://doi.org/10.1515/humaff-2015-0005

*Gibson B, Vozikis G, and Weaver M (2013) Exploring governance issues in family firms. Small Enterprise Research 20(2): 87-97. https://doi-org.ezproxy.uow.edu.au/10.5172/ser.2013.20.2.87

*Gilinsky A, Santini C, Lazzeretti L, and Eyler R (2008) Desperately seeking serendipity: Exploring the impact of country location on innovation in the wine industry. International Journal of Wine Business Research 20(4): 302-320. https://doi.org/10.1108/17511060810919425

*Gill A, Maung MT, and Chowdhury RH (2016) Social capital of non-resident family members and small business financing: Evidence from an Indian state. International Journal of Managerial Finance 12(5): 558582. https://doi.org/10.1108/IJMF-01-2015-0001

*Gómez-Mejía LR, Cruz C, Berrone P, and De Castro JO (2011) The bind that ties: Socioemotional wealth preservation in family firms. The Academy of Management Annals 5(1): 653-707.

http://dx.doi.org/10.1080/19416520.2011.593320

*Gómez-Mejía LR, Takács Haynes K, Núñez-Nickel K, Jacobson KJL, and Moyano-Fuentes, J (2019) Socioemotional wealth and business risks in family-controlled firms: Evidence from Spanish olive oil mills. Administrative Science Quarterly 52(1): 106-137. https://doi.org/10.2189/asqu.52.1.106

*Gómez-Mejía LR, Patel PC, and Zellweger TM (2018) In the horns of the dilemma: Socioemotional wealth, financial wealth, and acquisitions in family firms. Journal of Management 44(4): 1369-1397.

http://dx.doi.org/101177/0149206315614375 
*Gözen A and Ülgen B (2018) The relationship between organizational ambidexterity and family business performance. International Journal of Commerce and Finance 4(2): 94-107. ProQuest document ID 2153732807

*Grossmann S and Von Schlippe (2015) Family businesses: Fertile environments for conflict. Journal of Family Business Management 5(2): 294-314. https://doi.org/10.1108/JFBM-11-2014-0038

${ }^{*}$ Grote J (2003) Conflicting generations: A new theory of family business rivalry. Family Business Review 16(2): 113-124. https://doi.org/10.1111/j.1741-6248.2003.00113.x

*Gupta V and Levenburg N (2012) Cultures, ideologies, and family businesses. Journal of Family Business Management 2(1): 57-75. https://doi.org/10.1108/20436231211216420

Habbershon TG and Williams ML (1999) A resource-based framework for assessing the strategic advantages of family firms. Family Business Review 12(1): 1-25.

https://doi.org/10.1111/j.1741-6248.1999.00001.x

Handy C (1994) The Age of Paradox. Cambridge, MA: Harvard Business School Press. https://archive.org/details/ageofparadox00char

*Härtel CEJ, Bozer G, and Levin L (2009) Family business leadership transition: How an adaptation of executive coaching may help. Journal of Management and Organization 15(3): 378-391. ProQuest document ID 233256508

Hayton J, Chandler GN, and DeTienne DR (2011) Entrepreneurial opportunity identification and new firm development processes: A comparison of family and non-family new ventures. International Journal of Entrepreneurship and Innovation Management 13(1): 80-94. https://doi.org/10.1504/IJEIM.2011.038445

*Hernández-Linares R and López-Fernández MC (2018) Entrepreneurial orientation and the family firm: Mapping the field and tracing a path for future research. Family Business Review 31(3): 318-351. https://doi.org/10.1177/0894486518781940

*Herrero I and Hughes M (2019, forthcoming) When family social capital is too much of a good thing. Journal of Family Business Strategy. https://doi.org/10.1016/j.jfbs.2019.01.001

*Hiebl MRW and Mayrleitner B (2017) Professionalization of management accounting in family firms: The impact of family members. Review of Managerial Science 11(Dec): 1-32.

https://doi.org/10.1007/s11846-017-0274-8

*Hjorth D and Dawson A (2016) The burden of history in the family business organization. Organization Studies 37(8): 1089-1111. https://doi.org/10.1177/0170840615613375

Hmieleski KM and Baron RA (2009) Entrepreneurs' optimism and new venture performance: A social cognitive perspective. Academy of Management Journal 52(3): 473-488.

http://dx.doi.org/10.5465/AMJ.2009.41330755

*Hoffman J, Hoelscher M, and Sorenson R (2006) Achieving sustained competitive advantage: A family capital theory. Family Business Review 19(2): 135-145.

https://doi.org/10.1111/j.1741-6248.2006.00065.x

${ }^{*}$ Holt DT and Daspit JJ (2015) Diagnosing innovation readiness in family firms. California Management Review 58(1): 82-96. https://doi.org/10.1525/cmr.2015.58.1.82

*Horgos D (2013) Global sourcing: a family-firm's perspective. Journal of Small Business and Entrepreneurship 26(3): 221-240. https://doi.org/10.1080/08276331.2013.808028

*Howorth C, Wright M, Westhead P, and Allcock D (2016) Company metamorphosis: Professionalization waves, family firms and management buyouts. Small Business Economics 47(3): 803-817.

https://doi.org/10.1007/s11187-016-9761-6 
*Huang Y-C, Yang M-L, Wong, Y-J (2016) The effect of internal factors and family influence on firms' adoption of green product innovation. Management Research Review 39(10): 1167-1198. https://doi.org/10.1108/MRR-02-2015-0031

*Jaskiewicz P, González VM, Menéndez S, and Schiereck D (2005) Long-run IPO performance analysis of German and Spanish family-owned businesses. Family Business Review 18(3): 179-202.

https://doi.org/10.1111/j.1741-6248.2005.00041.x

*Jaskiewicz P, Uhlenbruck K, and Balkin DB (2013) Is nepotism good or bad? Types of nepotism and implications for knowledge management. Family Business Review 26(2):121-139.

https://doi.org/10.1177/089448651247084

Jaskiewicz P, Combs JG, and Rau SB (2015) Entrepreneurial legacy: Toward a theory of how some family firms nurture transgenerational entrepreneurship. Journal of Small Business Venturing 30: 29-49. http://dx.doi.org/10.1016/i.jbusvent.2014.07.001

*Jaskiewicz P, González VM, Menéndez S, and Schiereck D (2005) Long-run IPO performance analysis of German and Spanish family-owned businesses. Family Business Review 18(3): 179-202.

https://doi.org/10.1111/j.1741-6248.2005.00041.x

*Hamilton E (2006). Whose story is it anyway? Narrative accounts of the role of women in founding and establishing family businesses. International Small Business Journal 24(3): 253-271.

https://doi.org/10.1177/0266242606063432

*Hatum A, Silvestri L, Vassolo RS, and Pettigrew A (2012) Organizational identity as an anchor for adaptation: An emerging market perspective. International Journal of Emerging Markets 7(3): 305-334. https://doi.org/10.1108/17468801211237063

*Huang X, Chen L, Xu E, Lu F, and Tam KC (2019) Shadow of the prince: Parent-incumbents' coercive control over child-successors in family organizations. Administrative Science Quarterly. https://doi.org/10.1177/0001839219870449

*Hubler TM (2005) Forgiveness as an intervention in family-owned business: A new beginning. Family Business Review 18(2): 95-103. https://doi.org/10.1111/j.1741-6248.2005.00034.x

*Ingram AE, Lewis MW, Barton S, and Gartner WB (2016) Paradoxes and innovation in family firms: The role of paradoxical thinking. Entrepreneurship Theory and Practice 40(1): 161-176.

https://doi.org/10.1111/etap.12113

*Irava W and Moores K (2010) Clarifying the strategic advantage of familiness: Unbundling its dimensions and highlighting its paradoxes. Journal of Family Business Strategy 1(3): 131-144. https://doi.org/10.1016/i.jfbs.2010.08.002

*Kidwell RE, Eddleston KA, and Kellermanns FW (2018) Learning bad habits across generations: How negative imprints affect human resource management in the family firm. Human Resource Management Review 28: 5-17. https://doi.org/10.1016/i.hrmr.2017.05.002

*Kao M, Kuo A, and Chang Y (2013) How family control influences FDI entry mode choice. Journal of Management and Organization 19(4): 367-385. https://doi.org/10.1017/jmo.2013.23

*Kobrak C (2009) Family finance: Value creation and the democratization of cross-border governance. Enterprise \& Society 10(1): 38-89. https://doi.org/10.1093/es/khn103

*Kogut CS and Fleck D (2017) Professional versus family management in Brazilian fashion retail companies: Exploring value-investors' perceptions. EBAPE.BR 15(3): 559-573.

http://dx.doi.org/10.1590/1679-395156974 
*Konopaski M, Jack S, and Hamilton E (2015) How family business members learn about continuity. Academy of Management Learning \& Education 14(3): 347-364. https://doi.org/10.5465/amle.2014.0244

*Kotlar J, De Massis A, Fang H, and Frattini F (2014) Strategic reference points in family firms. Small Business Economics 43(3): 597-619. https://doi.org/10.1007/s11187-014-9556-6

*Kubíček A and Machek 0 (2018) Gender-related factors in family business succession: A systematic literature review. Review of Managerial Science. https://doi.org/10.1007/s11846-018-0278-z

*Kuss MX and Fumagalli LAW (2016) Strategies for family business professionalization in the gastronomic field. Revista Brasileira de Estratégia. 9(1): 95-112.

http://dx.doi.org/10.7213/rebrae.09.001.A006

*Lane S, Astrachan J, Keyt A, and McMillan K (2006) Guidelines for family business boards of directors. Family Business Review 19(2): 147-167. https://doi.org/10.1111/i.1741-6248.2006.00052.x

*Lappalainen J and Niskanen M (2013) Behavior and attitudes of small family firms towards different funding sources. Journal of Small Business and Entrepreneurship 26(6): 579-599. https://doi.org/10.1177/0894486517736958

*Lattuch F (2019) Family firm innovation strategy: Contradictions and tradition. Journal of Business Strategy 40(3): 36-42. https://doi.org/10.1108/JBS-03-2018-0046

Le Breton-Miller, I and Miller, D (2015) Learning stewardship in family firms: For family, by family, across the life cycle. Academy of Management Learning \& Education 14(3): 386-399.

http://dx.doi.org/10.5465/amle.2014.0131

*Lee KS, Lim GH, and Lim WS (2003) Family business succession: Appropriation risk and choice of successor. Academy of Management Review 28(4): 657-666.

https://doi.org/10.5465/amr.2003.10899446

*Lee S, Phan PH, and Yoshikawa T (2008) The role of the board and its interaction with the successor's human capital in the Asian family enterprise. Multinational Business Review 16(2): 65-88. https://doi.org/ https://doi-org/10.1108/1525383X200800008

Lewandowsky S and Thomas JL (2009) Expertise: Acquisition, limitations, and control. Reviews of Human Factors and Ergonomics 5(1): 140-165. https://doi.org/10.1518/155723409x448044

Lewis MW (2000) Exploring paradox: Toward a more comprehensive guide. Academy of Management Review 25(4): 760-776. https://doi.org/10.5465/amr.2000.3707712

Li J and Tang Y (2010) CEO hubris and firm risk taking in China: The moderating role of managerial discretion. Academy of Management Journal 53(1): 45-68. https://doi.org/10.5465/amj.2010.48036912

Li J, Wang J, and Fan W (2011) Yin yang and company growth: A case study of a coal company of Shanxi in China. Chinese Management Studies 5(4): 380-393. https://doi.org/10.1108/17506141111183154

*Lin S and Wang S, 2019. How does the age of serial entrepreneurs influence their re-venture speed after a business failure? Small Business Economics 52(3): 651-666.

https://doi.org/10.1007 s11187-017-9977-0

*Litz R (2011) Double roles, double binds? Double bind theory and family business research. In A Carsrud and M Brännback, Understanding Family Businesses: Undiscovered Approaches, Unique Perspectives, and Neglected Topics. London: Springer, pp. 115-132. https://doi.org/10.1007\%2F978-1-4614-0911-3

*Litz RA, Pearson AW, and Litchfield S (2012) Charting the future of family business research: Perspectives from the field. Family Business Review 25(1): 16-32.

https://doi.org/10.1177/0894486511418489 
*Llach J, Marquès P, Bikfalvi A, Simon A, and Kraus S (2012) The innovativeness of family firms through the economic cycle. Journal of Family Business Management 2(2): 96-109.

https://doi.org/10.1108/20436231211261853

*Luo X and Chung C-N (2005) Keeping it all in the family: The role of particularistic relationships in business group performance during institutional transition. Administrative Science Quarterly 50(3): 404439. https://doi.org/10.2189/asqu.2005.50.3.404

*Luo Y, Huang Y, and Wang SL (2012) Guanxi and organizational performance: A meta-analysis. Management and Organization Review 8(1): 139-172. https://doi.org/10.1111/j.17408784.2011.00273.x

Madison K, Holt DT, and Kellermanns FW (2016) Viewing family firm behavior and governance through the lens of agency and stewardship theories. Family Business Review 29(1): 69-93.

https://doi.org/10.1177/0894486515594292

*Mahto RV, Ahluwalia S, and Khanin D (2014) Psychological ownership of family firm successors: A conceptual approach. Small Business Institute Journal 10(2): 65-76.

https://scholar.google.com/citations?user=AnWeZ9AAAAAJ\&hl=en

*Manzaneque M, Ramírez Y, and Diéguez-Soto J (2017) Intellectual capital efficiency, technological innovation and family management. Innovation Organization \& Management 19(2): 167-188. http://dx.doi.org/10.1080/14479338.2016.1272828

*Marjański A, Sułkowski Ł, Marjańska-Potakowska J, and Staniszewska K (2019) Social capital drives SME growth: A study of family firms in Poland. German Journal of Human Resource Management, 33(3): 280-304. https://doi.org/10.1177/2397002219847668

*Marler LE, Botero IC, and De Massis A (2017) Succession-related role transitions in family firms: The impact of proactive personality. Journal of Management Issues 29(1): 57-81.

https://scholar.google.com/citations?user=JnwXKvgAAAAJ\&hl=en

*Marshall JP, Sorenson R, Brigham K, Wieling E, Reifman A, and Wampler RS (2006) The paradox for the family firm CEO: Owner age relationship to succession-related processes and plans. Journal of Business Venturing 21(3): 348-368. https://doi.org/10.1016/i.jbusv ent.2005.06.004

*Mazzelli A, Kotlar J, and De Massis A (2018) Blending in while standing out: Selective conformity and new product introduction in family firms. Entrepreneurship Theory and Practice 42(2): 206-230. https://doi.org/10.1177/1042258717748651

McDermott CM and Colarelli O'Connor G (2002) Managing radical innovation: An overview of emergent strategy issues. Journal of Product Innovation Management 19(6): 424-438. http://dx.doi.org/10.1016/S0737-6782(02)00174-1

*Meenakshi G (2018) Case Analysis III: Conflicts in a Closely Held Family Business: Durga and Company. Vision 22(1): 114-115. https://doi.org/10.1177/0972262917750653

*Merchant P, Kumar A, and Mallik D (2018) Factors influencing family business continuity in Indian small and medium enterprises (SMEs). Journal of Family and Economic Issues 39: 177-190.

https://doi.org/10.1007/s10834-017-9562-3

Merton R, Reader G, and Kendall P (1957) The student physician. Cambridge, MA: Harvard University Press. https://www.hup.harvard.edu/catalog.php?isbn=9780674366831

Meyer JW and Rowan B (1977) Institutionalized organizations: Formal structure as myth and ceremony. The American Journal of Sociology 83(2): 340-363.

http://links.jstor.org/sici?sici=0002-

9602\%28197709\%2983\%3A2\%3C340\%3AIOFSAM\%3E2.0.CO\%3B2-3 
*Michiels A, Voordeckers W, Lybaert N, and Steijvers T (2015) Dividends and family governance practices in private family firms. Small Business Economics 44(2): 299-314.

https://doi.org/10.1177/0894486517736958

*Mihic MM, Arsic SM, Arsic MZ (2015) Impacts of entrepreneurs' stress and family members on SMEs' business success in Serbian family-owned firms. Journal of East European Management Studies 20(4): 452-483. https://doi.org/10.1688/JEEMS-2015-04-Mihic

*Mitchell JR, Hart TA, Valcea S, and Townsend DM (2009) Becoming the boss: Discretion and postsuccession success in family firms. Entrepreneurship Theory and Practice 33(6): 1201-1218. https://doi.org/101111/i1540-6520200900341x

*Moașa H (2017) Paradoxes in a family business. Bulletin of the Transilvania University of Brasov 10(1): 99-108. http://webbut.unitbv.ro/BU2017/Series\%20VII/2017/BULETIN\%20I\%20PDF/13 Moasa.pdf

*Mohan GJ and Padhi P (2018) Hidden leverage in conglomerates: An unintended systemic risk. IUP Journal of Applied Finance 24(1): 5-20. ProQuest document ID: 2003276948

*Monreal-Pérez J and Sánchez-Marín G (2017) Does transitioning from family to non-family controlled firm influence internationalization? Journal of Small Business and Enterprise Development 24(4): 775-792. https://doi.org/10.1108/JSBED-02-2017-0029

*Monroy VIB, Solís ERR, and Rodríguez-Aceves L (2015) Familiness and its relationship with performance in Mexican family firms. Academy of Strategic Management Journal 14(2): 1-21. ProQuest document ID 1760498981

*Moores K (2009) Paradigms and theory building in the domain of business families. Family Business Review 22(2): 167-180. https://doi.org/10.1177/0894486509333372

Moores K and Barrett M (2002) Learning family business: Paradoxes and pathways. Hampshire, England: Ashgate Publishing Company. https://library.bond.edu.au/publication/learning-family-businessparadoxes-and-pathways

*Mori N and Goodluck C (2019) The role of boards of directors of family-owned microfinance institutions. Journal of Family Business Management 9(1): 79-97. https://doi.org/10.1108//FBM-11-2017-0040

Müller S (2017) Performance Implications of Family Firms' Idiosyncratic Responses to Recessionary Pressures: A Comparative Study on Family Firm and Non-Family Firm Behaviour over the Business Cycle in Norway. Thesis. https://pdfs.semanticscholar.org/fccf/f74ae5be9c9f69ae46e7c48412eadf2527de.pdf

Nahapiet J and Ghoshal S (1998) Social capital, intellectual capital, and the organizational advantage. Academy of Management Review 23(2): 242-266. https://www.jstor.org/stable/259373

*Naldi L, Nordqvist M, Sjöberg K, and Wiklund J (2007) Entrepreneurial orientation, risk taking, and performance in family firms. Family Business Review 20(1): 33-47. https://doi.org/10.1111/j.1741$\underline{6248.2007 .00082 . x}$

*Nordqvist M, Habbershon TG, and Melin L (2008) Transgenerational entrepreneurship: Exploring entrepreneurial orientation in family firms. In Landström H, Smallbone D, Crijns H, and Laveren E (Eds.), Entrepreneurship, Sustainable Growth and Performance: Frontiers in European Entrepreneurship Research. London: Edward Elgar, pp. 93-116.

*Nosé L, Korunka C, Frank H, and Danes, SM (2017) Decreasing the effects of relationship conflict on family businesses: The moderating role of family climate. Journal of Family Issues, 38(1): 25-51. https://doi.org/10.1177/0192513X15573869

*Ochiai Y (2016) Business succession and successor legitimacy in well-established family companies in Japan. International Journal of Business and Information 11(3): 316-340.

https://ijbi.org/ijbi/article/view/182/151 
*Osnes G, Uribe A, Hök L, Hou OY, and Haug M (2016) Autonomy and paradoxes in family ownership: Case studies across cultures and sectors. Journal of Family Business Management 7(1): 93-110.

https://doi.org/10.1108/JFBM-03-2016-0004.

*Osnes G, Hök L, Yanli Hou O, Haug M, Grady V, and Grady J (2019) Strategic plurality in intergenerational hand-over. Journal of Family Business Management 9(2): 149-174. https://doi.org/10.1108/JFBM-06$\underline{2018-0018}$

*Padilla-Meléndez A, Dieguez-Soto J, and Garrido-Moreno A (2015) Empirical research on innovation in family business: Literature review and proposal of an integrative framework. Revista Brasileira de Gestão de Negócios 17(56): 1064-1089. https://doi.org/10.7819/rbgn.v17i56.1915

*Parada MJ and Gimeno A (2016) Understanding characteristics of long-term value creating family businesses. Effective Executive 19(4): 43-54. ProQuest document ID1865383453

*Patalinghug JC (2016) A case study of organizational form: Hershey versus Mars. E-Journal of Social \& Behavioural Research in Business 7(2): 29-48. ProQuest document ID1856850532

*Pathak AA, and Kandathil G, (2019) Strategizing in small informal retailers in India: Home delivery as a strategic practice. Asia Pacific Journal of Management (Jun): 1-27. https://doi.org/10.1007/s10490-019$\underline{09662-4}$

*Peake WO, Cooper D, Fitzgerald MA, and Muske G (2017) Family business participation in community social responsibility: The moderating effect of gender. Journal of Business Ethics 142(2): 325-343.

https://doi.org/10.1007/s10551-015-2716-z

*Pearson AW, Bergiel E, and Barnett T (2014) Expanding the study of organizational behaviour in family business: Adapting team theory to explore family firms. European Journal of Work and Organizational Psychology 23(5): 657-664. https://doi.org/10.1080/1359432X.2014.911174

*Pieper TM, Klein SB, and Jaskiewicz P (2008) The impact of goal alignment on board existence and top management team composition: Evidence from family-influenced businesses. Journal of Small Business Management 46(3): 372-394. https://doi.org/10.1080/1359432X.2014.911174

*Pieper TM, Smith AD, Kudlats J, and Astrachan JH (2015) Article commentary: The persistence of multifamily firms: Founder imprinting, simple rules, and monitoring processes. Entrepreneurship Theory and Practice 39(6): 1313-1337. https://doi.org/10.1111/etap.12173

*Ponroy JV, Lê P, and Pradies C (2019) In a family way? A model of family firm identity maintenance by non-family members. Organization Studies 40(6): 859-886. https://doi.org/10.1177/0170840619836707

*Pontet SBd, Wrosch C, and Gagne M (2007) An exploration of the generational differences in levels of control held among family businesses approaching succession. Family Business Review 20(4): 337-354. https://doi.org/10.1177/0170840619836707

Poole MS and Van de Ven AH (1989) Using paradox to build management and organization theories. Academy of Management Review 14(4): 562-578. https://doi.org/10.5465/amr.1989.4308389

*Pooser DM, Wang P, and Barrese JA (2017) A governance study of corporate ownership in the insurance industry. Journal of Insurance Issues 40(1): 23-60. Handle: RePEc:wri:journl:v:40:y:2017:1:1:p: 23-60

PwC (2017) Same passion, different paths: How the next generation of family business leaders are making their mark. Available at https://www.pwc.com/gx/en/family-business-services/assets/next-gen-study2017.pdf

*Ramachandran K (2015) The 10 Commandments for Family Business. New Delhi: SAGE Response Books. 
*Reisinger S and Lehner, JM (2015) Navigating a family business through a changing environment: Findings from a longitudinal study. Review of Managerial Science 9(2): 411-429.

https://doi.org/10.3389/fpsyg.2014.01335

Ren S and Zhu Y (2017) Developing family businesses through ongoing learning. Journal of General Management 41(4): 51-70. https://doi.org/10.1177/030630701604100404

*Reuber AR (2016) An assemblage-theoretic perspective on the internationalization processes of family firms. Entrepreneurship Theory and Practice 40(6): 1269-1286. https://doi.org/10.1111/etap.12243

*Richards M, Kammerlander N, and Zellweger T (2019, forthcoming) Listening to the heart or the head? Exploring the "willingness versus ability" succession dilemma. Family Business Review.

http://dx.doi.org/10.1177/0894486519833511

*Roessl D (2016) Family businesses and interfirm cooperation. Family Business Review 18(3): 203-214. https://doi.org/10.1111/j.1741-6248.2005.00042.x

*Sahasranamam S, Arya B, and Sud M (2019) Ownership structure and corporate social responsibility in an emerging market. Asia Pacific Journal of Management (Jun): 1-28. https://doi.org/10.1007/s10490$\underline{019-09649-1}$

*Salvato C, Chirico F, Melin L, and Seidl D (2019, forthcoming) Coupling family business research with organization studies: Interpretations, issues, and insights. Organization Studies.

https://doi.org/10.1177/0170840619841402

Sambrook S (2005) Exploring succession planning in small, growing firms. Journal of Small Business and Enterprise Development 12(4): 579-594. https://doi.org/10.1108/14626000510628243

*Sanchez P, Daspit JJ, Holt DT, and Rutherford MW (2019, forthcoming) Family social capital in the family firm: A taxonomic classification, relationships with outcomes, and directions for advancement. Family Business Review. http://dx.doi.org/10.1177/0894486519836833

*Sanchez-Famoso V, Maseda A, and Iturralde T (2017) Family involvement in top management team: Impact on relationships between internal social capital and innovation. Journal of Management \& Organization 23(1): 136-162. http://dx.doi.org/10.1017/jmo.2016.2

Sarasvathy SD (2001) Causation and effectuation: Toward a theoretical shift from economic inevitability to entrepreneurial contingency. Academy of Management Review 26(2): 243-263.

https://doi.org/10.5465/AMR.2001.4378020

Sarasvathy SD (2009) Effectuation: Elements of Entrepreneurial Expertise. Cheltenham, Edward Elgar.

*Schäfer D, Stephan A, and Mosquera, JS (2017) Family ownership: Does it matter for funding and success of corporate innovations?·Small Business Economics 48: 931-951. http://dx.doi.org/10.1007/s11187$\underline{016-9813-y}$

*Schäffer U, Strauss E, and Zecher C (2015) The role of management control systems in situations of institutional complexity. Qualitative Research in Accounting \& Management 12(4): 395-424.

https://doi.org/10.1108/QRAM-01-2015-0010

Schulze WS, Lubatkin MH, Dino RN, and Buchholtz AK (2001) Agency relationships in family firms: Theory and evidence. Organization Science 12(2): 99-116. https://www.jstor.org/stable/3086050

*Schuman A, Stutz S, and Ward J (2010) Family Business as Paradox. London: Palgrave MacMillan.

*Sciascia S and Mazzola P (2008) Family involvement in ownership and management: Exploring nonlinear effects on performance. Family Business Review 21(4): 331-345.

https://doi.org/10.1177/08944865080210040105 
Scott WR (1987) The adolescence of institutional theory. Administrative Science Quarterly 32(4): 493-511. https://www.jstor.org/stable/2392880

*Seaman C, Bent R, and Unis A (2016) The role of context understanding South Asian family firms in Scotland and the succession paradox. International Journal of Management Practice 9(4): 433-447. http://dx.doi.org/10.1504/IJMP.2016.079619

*Seaman C, Mcquaid R, and Pearson M (2014) Networks in family business: A multi-rational approach. International Entrepreneurship and Management Journal 10(3): 523-537. https://doi.org/10.1007/s11365-014-0297-4

*Serrano-Bedia AM, López-Fernández MC, and Garcia-Piqueres G (2016) Analysis of the relationship between sources of knowledge and innovation performance in family firms. Innovation: Management, Policy \& Practice 18(4): 489-512. https://doi.org/10.1080/14479338.2016.1233826

Sharma P, Chrisman JJ, and Gersick K (2012) 25 years of Family Business Review. Family Business Review 25(1): 5-15. http://dx.doi.org/10.1177/0894486512437626

Sharma P and Irving PG (2005) Four bases of family business successor commitment: Antecedents and consequences. Entrepreneurship Theory and Practice 29(1): 13-33. https://doi.org/10.1111/j.15406520.2005.00067.x

Simonton DK (2014) Creative performance, expertise acquisition, individual differences, and developmental antecedents: An integrative research agenda. Intelligence 45: 66-73.

http://dx.doi.org/10.1016/j.intell.2013.04.007

*Sinha A, Pandey J, and Varkkey B (2017) Professionalizing religious family-owned organizations: An examination of human resource challenges. South Asian Journal of Management 24(2): 7-24. ProQuest document ID1938166369

Sirmon DG and Hitt MA (2003) Managing resources: Linking unique resources, management, and wealth creation in family firms. Entrepreneurship Theory and Practice 27(4): 339-358.

https://doi.org/10.1111/1540-8520.t01-1-00013

Spence MT and Brucks M (1997) The moderating effects of problem characteristics on experts' and novices' judgments. Journal of Marketing Research, 34(2): 233-247.

https://doi.org/10.1177/002224379703400204

Stafford K, Duncan KA, Dane S, and Winter M (1999) A research model of sustainable family businesses. Family Business Review 12(3): 197-208. https://doi.org/10.1111/j.1741-6248.1999.00197.x

*Stamm, IK (2016) Coordination tasks and negotiation modes of linked lives in entrepreneurial families. Journal of Marriage and Family 78(Aug): 939-956. https://doi.org/10.1111/iomf.12304

*Steier LP (2009) Familial capitalism in global institutional contexts: Implications for corporate governance and entrepreneurship in East Asia. Asia Pacific Journal of Management 26(3): 513-535. https://doi.org/10.1007/s10490-008-9117-0

*Steier, LP, Chua, JH, and Chrisman, JJ (2009) Embeddedness perspectives of economic action within family firms. Entrepreneurship Theory and Practice, 33(6): 1157-1167. https://doi.org/10.1111/j.15406520.2009.00338.x

*Sultan S, de Waal A, and Goedegebuure R (2017) Analyzing organizational performance of family and non-family businesses using the HPO framework. Journal of Family Business Management 7(10): 242-255. https://doi.org/10.1108/IFBM-07-2017-0021

*Sundaramurthy C (2008) Sustaining trust within family businesses. Family Business Review 21(1): 89102. https://doi.org/10.1111/j.1741-6248.2007.00110.x 
Tagiuri R and Davis J (1996) Bivalent attributes of the family firm. Family Business Review 9(2): 199-208. https://doi.org/10.1111/j.1741-6248.1996.00199.x

*Trabelsi D, Aziz S, and Lilti J-J (2019) A behavioral perspective on corporate dividend policy: Evidence from France. Corporate Governance 19(1): 102-119. https://doi.org/10.1108/CG-02-2018-0077

Tranfield D, Denyer D, and Smart P (2003) Towards a methodology for developing evidence-informed management knowledge by means of systematic review. British Journal of Management 14: 207-222. https://doi.org/10.1111/1467-8551.00375

Tsui-Auch LS and Lee YJ (2003) The state matters: Management models of Singaporean Chinese and Korean business groups. Organization Studies 24(4): 507-534.

https://doi.org/10.1177/1350507603034002003

*Ullah F and Smith RA (2015) The 'fairness paradox' and small-firm growth resistance strategies. World Journal of Entrepreneurship, Management and Sustainable Development 11(3): 154-175.

https://doi.org/10.1108/WJEMSD-02-2015-0005

*Umans I, Lybaert N, Steijvers T, and Voordeckers W (2018, forthcoming) Succession planning in family firms: Family governance practices, board of directors, and emotions. Small Business Economics. 1-19. https://doi.org/10.1007/2Fs11187-018-0078-5

Uzzi B (1999) Embeddedness in the making of financial capital: How social relations and networks benefit firms seeking financing. American Sociological Review 64(4): 481-505. ProQuest document ID218821080

*Vallejo MC (2009) Analytical model of leadership in family firms under transformational theoretical approach: An exploratory study. Family Business Review 22(2): 136-150.

https://doi.org/10.1177/0894486508327892

*Verbeke A, Yuan W, and Kano (2019, forthcoming) A values-based analysis of bifurcation bias and its impact on family firm internationalization. Asia Pacific Journal of Management.

https://doi.org/10.1007/s10490-018-9598-4

*Vincent M, Uhlaner LM, De Massis A, and Laveren E (2019) Family-centered goals, family board representation, and debt financing. Small Business Economics 53(1): 269-286. ProQuest document ID218821080

*Ward J (2004) Perpetuating the Family Business: 50 Lessons Learned From Long Lasting, Successful Families in Business. London: Palgrave Macmillan. http://doi.org/10.1057/2F9780230505995

*Williams RL Jr, Pieper TM, Kellermanns FW, and Astrachan JH (2019, forthcoming) Family business goal formation: A literature review and discussion of alternative algorithms. Management Review Quarterly. 121. https://doi.org/10.1007/s11301-019-00155-8

*Xu L 2014 A tale of trinity in founder's identity: The case of new venture creation. Journal of Management Policy and Practice 15(5): 11-31. ProQuest document ID1648032175 http://www.nabusinesspress.com/IMPP/XuL Web15 5 .pdf

Yan S, Ferraro F, and Almandoz J (2019) The rise of socially responsible investment funds: The paradoxical role of the financial logic. Administrative Science Quarterly, 64(2): 466-501.

https://doi.org/101177/0001839218773324

Yang X, Li J, Stanley LJ, Kellermanns FW, and Li X (2018, forthcoming) How family firm characteristics affect internationalization of Chinese family SMEs. Asia Pacific Journal of Management. pp. 1-32. https://doi.org/10.1007/2Fs10490-018-9579-7

*Yusof M, Leilanie MN, and Hoopes JE (2014) Virtuous CSR: An Islamic family business in Malaysia. Journal of Family Business Management 4(2): 133-148. https://doi.org/10.1108/IFBM-07-2013-0016 
*Zahra SA (2012) Organizational learning and entrepreneurship in family firms: Exploring the moderating effect of ownership and cohesion. Small Business Economics 38(1): 51-65. https://doi.org/10. 1007/s 11187-010-9266-7

*Zahra SA and Sharma P (2016) Family business research: A strategic reflection. Family Business Review 17(4): 331-346. https://doi.org/10.1111/j.1741-6248.2004.00022.x

*Zellweger, T (2011) Toward a paradox perspective of family firms: The moderating role of collective mindfulness of controlling families. In L Melin, M Nordqvist, and P Sharma (Eds.), The SAGE Handbook of Family Business (pp. 1-14). Thousand Oaks, USA: Sage.

*Zhang Z and Reay T (2018) Managing the Yin and Yang of family capital: A study of Chinese immigrant entrepreneurs. Entrepreneurship and Regional Development 30(7-8): 722-748.

https://doi.org/10.1080/08985626.2018.1457085

*Zhao, J (2014) Shame and discipline: The practice and discourse of a 'Confucian model' of management in a family firm in China. Critique of Anthropology 34(2): 129-152.

https://doi.org/10.1177/0308275X13519272

*Zhao J, Carney M, Zhang S, and Zhu L (2018) How does an intra-family succession effect strategic change and performance in China's family firms? Asia Pacific Journal of Management.

https://doi.org/10.1007/s10490-018-9568-x.

*Zona F (2015) Board ownership and processes in family firms. Small Business Economics 44(1): 105-122. https://doi.org/10.1007/s11187-014-9587-z

*Zou W, Chiu Y, and Hsu C (2014) Performance appraisals between family businesses and non-family businesses. International Journal of Organizational Innovation (Online) 7(1): 36-45. ProQuest document ID1544214432 
Appendix 1: Summary of literature review results.

Available at https://doi.org/10.6084/m9.figshare.10000553 
Figure 1: The 4Ls of Family Business

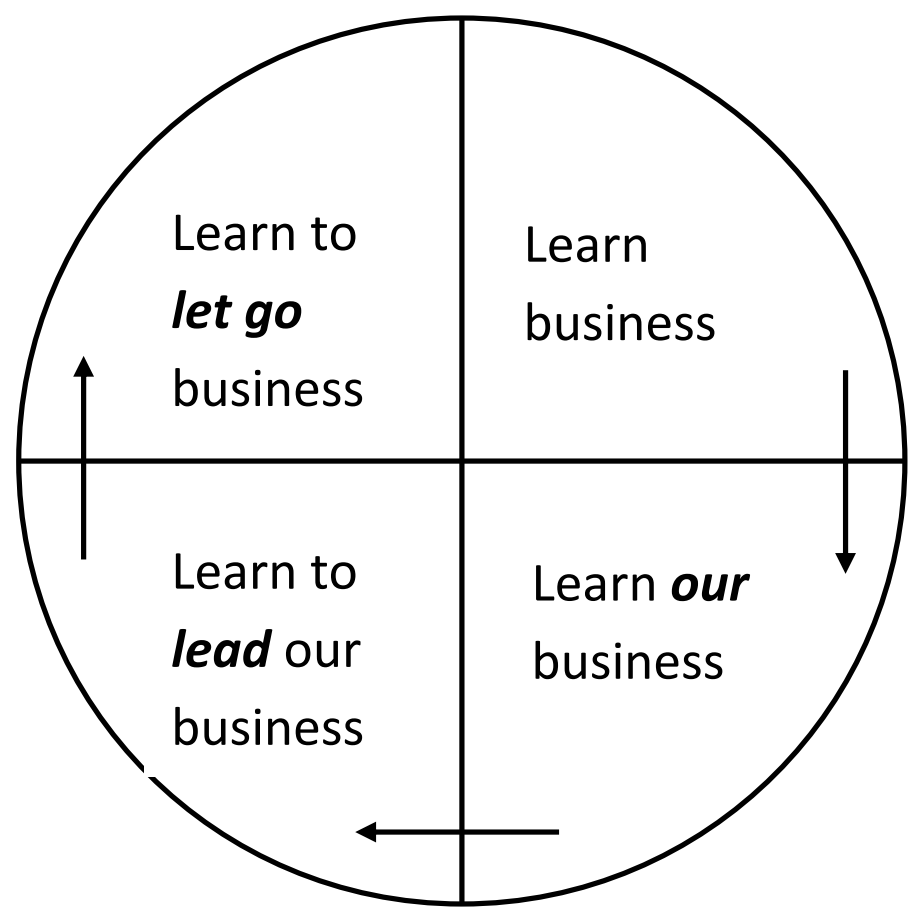

Source: Adapted from Moores and Barrett (2002) 
Figure 2: Extending the 4Ls by recombining its elements

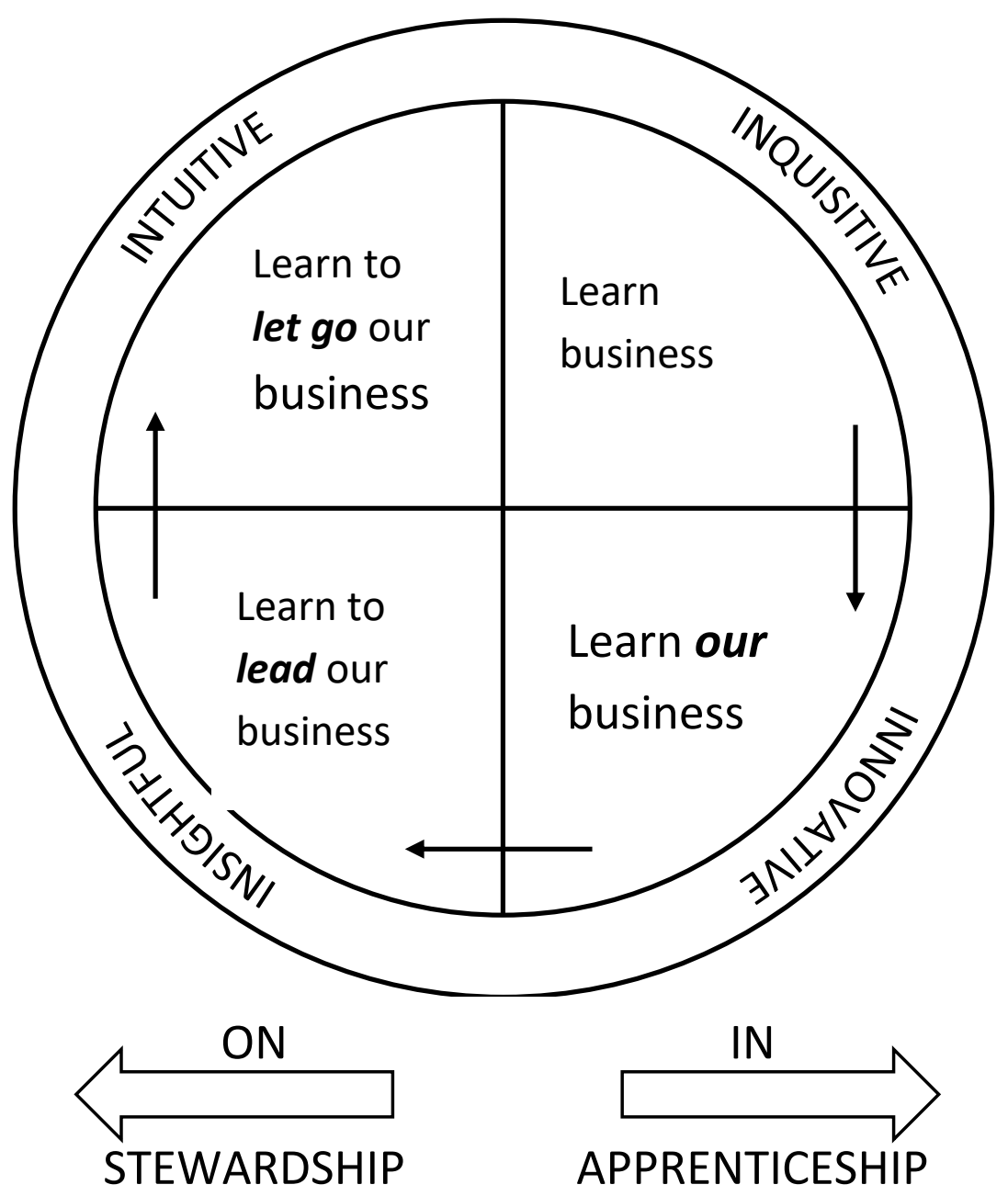


Table 1: Relationships among 'what' and 'how' paradoxes

\begin{tabular}{|c|c|c|c|}
\hline \multicolumn{2}{|r|}{ WHAT } & \multicolumn{2}{|l|}{ HOW } \\
\hline $\begin{array}{c}\text { Paradox } \\
\text { categories } \\
\text { of Ingram et } \\
\text { al. }(2016) \& \\
\text { Schuman et } \\
\text { al. }(2010) \\
\end{array}$ & \multicolumn{2}{|c|}{ Paradoxes identified in literature } & 4Ls paradoxes \\
\hline $\begin{array}{c}\text { TRADITION } \\
\text { vS. } \\
\text { CHANGE }\end{array}$ & $\begin{array}{l}\text { - } \text { Embeddedness } \\
\text { - Ability vs. willingness to } \\
\text { innovate } \\
\text { - Risk willing/risk averse } \\
\text { - Entrepreneurial success }\end{array}$ & $\begin{array}{ll}\text { - } & \text { Roots and wings } \\
\text { - } & \text { Chaos/continuity } \\
\text { - } & \text { Family vs. human capital } \\
\text { - } & \text { Managing chaos with } \\
\text { simplicity } \\
\text { - Conformity fuels } \\
\text { innovation } \\
\text { - Innovation through } \\
\text { tradition }\end{array}$ & $\begin{array}{l}\text { CONTINUING } \\
\text { DIFFERENTLY } \\
\text { (L2) }\end{array}$ \\
\hline $\begin{array}{l}\text { FAMILY } \\
\text { LIQUIDITY } \\
\text { VS. } \\
\text { BUSINESS } \\
\text { GROWTH }\end{array}$ & $\begin{array}{l}\text { - Embeddedness } \\
\text { - Ability vs. willingness to } \\
\text { innovate }\end{array}$ & $\begin{array}{l}\text { - } \text { Chaos/continuity } \\
\text { - Family vs. human capital } \\
\text { - Training reduces learning } \\
\text { - Managing chaos with } \\
\text { simplicity }\end{array}$ & $\begin{array}{c}\text { INFORMAL } \\
\text { FORMALITY (L3) }\end{array}$ \\
\hline $\begin{array}{l}\text { FOUNDER } \\
\text { CONTROL } \\
\quad \text { VS. } \\
\text { SUCCESSOR } \\
\text { AUTONOMY }\end{array}$ & $\begin{array}{l}\text { - Ability vs. willingness to } \\
\text { innovate } \\
\text { - Initiative } \\
\text { - Conformity/Nonconformity }\end{array}$ & $\begin{array}{l}\text { - } \text { Roots and wings } \\
\text { - } \text { International business } \\
\text { education } \\
\text { - Family vs. human capital } \\
\text { - } \text { Managing chaos with } \\
\text { simplicity } \\
\text { - Successor commitment or } \\
\text { competence }\end{array}$ & $\begin{array}{l}\text { INSIDE/OUTSIDE } \\
\text { (L1) } \\
\text { LEADING BY } \\
\text { LEAVING (L4) }\end{array}$ \\
\hline
\end{tabular}


Table 2: Some suggested research questions

\begin{tabular}{|c|c|c|}
\hline $\begin{array}{l}\text { Where } \\
\text { paradox } \\
\text { emerges }\end{array}$ & What & How \\
\hline \multicolumn{3}{|c|}{ Inside 4Ls (Research questions prompted from within the 4Ls framework) } \\
\hline $\begin{array}{l}\text { Learning } \\
\text { between } \\
\text { phases }\end{array}$ & $\begin{array}{c}\text { What learning happens between successive } \\
\text { developmental phases? }\end{array}$ & $\begin{array}{l}\text { How do family business leaders at L3 innovate } \\
\text { and manage paradoxical opposites when moving } \\
\text { from acknowledging tradition (L2) and the need } \\
\text { for change (L1)? }\end{array}$ \\
\hline & & $\begin{array}{l}\text { How likely are successors to be able and willing } \\
\text { to exercise discretion through 'entrepreneurial } \\
\text { agency' following succession? }\end{array}$ \\
\hline $\begin{array}{l}\text { Successor } \\
\text { discretion }\end{array}$ & $\begin{array}{c}\text { What specific forms of strategic change are } \\
\text { associated with greater successor } \\
\text { discretion? }\end{array}$ & $\begin{array}{l}\text { How likely are successors who have developed } \\
\text { confidence, self-efficacy, and legitimacy from } \\
\text { going outside the firm (L1) and/or previous } \\
\text { senior-level involvement, to display higher } \\
\text { successor discretion, evidenced by more } \\
\text { adventurous strategic change? }\end{array}$ \\
\hline $\begin{array}{l}\text { Initiative and } \\
\text { embeddedness }\end{array}$ & $\begin{array}{l}\text { What are the consequences of the initiative } \\
\text { and embeddedness paradoxes in family firm } \\
\text { successions? }\end{array}$ & $\begin{array}{l}\text { How do families cope with these paradoxes: } \\
\text { maintain tradition, change, or adopt paradoxical } \\
\text { thinking and continue differently? }\end{array}$ \\
\hline $\begin{array}{l}\text { Development } \\
\text { of innovation } \\
\text { strategy }\end{array}$ & $\begin{array}{l}\text { What individual and firm abilities are } \\
\text { needed to foster willingness to innovate? }\end{array}$ & $\begin{array}{l}\text { How do families cope with the uncertainty and } \\
\text { time demands of innovation? For example, are } \\
\text { family firms' long-term investment horizons and } \\
\text { patient capital used to manage the time needed } \\
\text { to produce tangible outcomes from innovation? } \\
\text { How can the continuity qualities of family firms } \\
\text { be used to develop more radical innovations } \\
\text { (market novelties)? }\end{array}$ \\
\hline \multirow{3}{*}{ Expertise } & $\begin{array}{l}\text { What novice-like behaviors (e.g. reliance on } \\
\text { lists of facts and heuristics; anchoring } \\
\text { biases) do aspiring leaders (at L1and } \\
\text { possibly L2) display as part of their } \\
\text { Inquisitive forms of learning? }\end{array}$ & $\begin{array}{l}\text { How are Inquisitive forms of learning used to } \\
\text { transcend novice-like behaviors at L1/L2? }\end{array}$ \\
\hline & $\begin{array}{l}\text { What expert-like behaviors do family } \\
\text { business leaders (at L3/L4) exhibit? }\end{array}$ & $\begin{array}{l}\text { How do problem solving and experiential } \\
\text { learning eventually enable very fast decisions } \\
\text { proceeding from expert Intuitions at L4? }\end{array}$ \\
\hline & $\begin{array}{l}\text { What decision types or errors trigger L4 } \\
\text { learning, e.g., incumbents recognize the } \\
\text { need to step back from day-to-day tasks? }\end{array}$ & $\begin{array}{c}\text { How can the expert insights of former } \\
\text { incumbents (L4/post L4) be used to assist } \\
\text { successor learning? }\end{array}$ \\
\hline \multicolumn{3}{|c|}{ Outside 4Ls (Research questions prompted by issues and frameworks adjacent to the $4 \mathrm{Ls}$ ) } \\
\hline $\begin{array}{l}\text { Effectuation } \\
\text { and new } \\
\text { venture } \\
\text { creation }\end{array}$ & $\begin{array}{l}\text { Which venture creation strategies are used } \\
\text { more by successors with longer outside } \\
\text { (L1)/senior internal experience than by less } \\
\text { experienced successors? }\end{array}$ & $\begin{array}{l}\text { How are effectuation and causation principles } \\
\text { absorbed during each of the 4Ls? }\end{array}$ \\
\hline $\begin{array}{l}\text { Bases of } \\
\text { successor } \\
\text { commitment }\end{array}$ & $\begin{array}{l}\text { What is the relationship between the bases } \\
\text { of successor commitment and an } \\
\text { individual's preceding or subsequent } \\
\text { engagement with 4Ls learning? }\end{array}$ & $\begin{array}{l}\text { How and when does mentoring by family } \\
\text { members produce affective commitment? } \\
\text { To what extent are different bases of } \\
\text { commitment to joining the family firm mediated }\end{array}$ \\
\hline
\end{tabular}




\begin{tabular}{|c|c|c|}
\hline & & $\begin{array}{l}\text { or moderated by successors' perceptions of their } \\
\text { own competence? }\end{array}$ \\
\hline $\begin{array}{l}\text { Institutional } \\
\text { logics }\end{array}$ & $\begin{array}{l}\text { Which institutional logics (family, financial, } \\
\text { social responsibility, etc.) shape the } \\
\text { formation of family firm goals over time? }\end{array}$ & $\begin{array}{l}\text { How do shifts in the strength of financial and } \\
\text { other institutional logics affect how successors } \\
\text { shape and implement competing family firm } \\
\text { goals e.g., financial and socio-emotional wealth? }\end{array}$ \\
\hline \multirow[t]{2}{*}{$\begin{array}{l}\text { Strategic } \\
\text { narratives }\end{array}$} & $\begin{array}{c}\text { Which narratives of aspiring successors aim } \\
\text { to change stakeholders' perceptions of } \\
\text { institutional logics and/or firm } \\
\text { performance? }\end{array}$ & \multirow[t]{2}{*}{$\begin{array}{l}\text { How are successors' use of narratives and their } \\
\text { political acumen related? }\end{array}$} \\
\hline & $\begin{array}{c}\text { Which narratives of reluctant successors } \\
\text { aim to discourage incumbents from } \\
\text { appointing them? }\end{array}$ & \\
\hline \multirow{3}{*}{$\begin{array}{l}\text { Firm } \\
\text { structures }\end{array}$} & \multirow{3}{*}{$\begin{array}{l}\text { Which structures are distinctive features of } \\
\text { family firms? }\end{array}$} & $\begin{array}{c}\text { How are firm structures used to manage aspects } \\
\text { of family firms' internal and external } \\
\text { environment? }\end{array}$ \\
\hline & & $\begin{array}{l}\text { How are family firm structures linked to 'simple } \\
\text { rules' for managing complexity? }\end{array}$ \\
\hline & & $\begin{array}{l}\text { Do some 'simple rules' lead to complex rather } \\
\text { than simple structures and processes? }\end{array}$ \\
\hline
\end{tabular}

